\title{
Review:
}

\section{Escalating insecticide resistance in Australian grain pests: contributing factors, industry trends and management opportunities}

Running title: Insecticide resistance challenges and opportunities in Australian grains

P.A. Umina ${ }^{\mathrm{a}, b^{*}}$, G. McDonald ${ }^{\mathrm{a}}$, J. Maino ${ }^{\mathrm{a}, \mathrm{b}}$, O. Edwards ${ }^{\mathrm{c}}$ and A.A. Hoffmann ${ }^{\mathrm{a}}$

\author{
${ }^{a}$ School of BioSciences, Bio21 Institute, The University of Melbourne, VIC 3068 \\ Australia \\ ${ }^{\mathrm{b}}$ cesar, 293 Royal Parade, Parkville, VIC 3052 Australia \\ ${ }^{\mathrm{c}}$ CSIRO Land \& Water, Underwood Ave, Floreat, WA 6014 Australia
}

This is the author manuscript accepted for publication and has undergone full peer review but has not been through the copyediting, typesetting, pagination and proofreading process, which may lead to differences between this version and the Version of Record. Please cite this article as doi:

This article is protected by copyright. All rights reserved. 
*corresponding author, pumina@unimelb.edu.au

This article is protected by copyright. All rights reserved. 


\begin{abstract}
Insecticide resistance is an ever-increasing problem that threatens food production globally. Within Australia, the grain industry has a renewed focus on resistance due to diminishing chemical options available to farmers and the increasing prevalence and severity of resistance encountered in the field. Chemicals are too often used as the major tool for arthropod pest management, ignoring the potent evolutionary forces from chemical selection pressures that lead to resistance. A complex of factors (biological, social, economic, political, climatic) have contributed to current trends in insecticide usage and resistance in the Australian grain industry. We review the status of insecticide resistance and provide a context for how resistance is currently managed. We discuss emerging technologies and research that could be applied to improve resistance management. This includes generating base-line sensitivity data for insecticides before they are launched, developing genetic diagnostics for the full complement of known resistances, expanding resistance monitoring programs, and utilizing new technologies. Additional benefits are likely to be achieved through a combination of industry awareness and engagement, risk modelling, adoption of IPM tactics, greater collaboration between industry stakeholders, and policy changes around chemical use and record keeping. The Australian grain context provides lessons for other agricultural industries.
\end{abstract}

Keywords: arthropod, insecticide resistance, stewardship, selection pressure, resistance management 


\section{Introduction}

Increased pressure on agricultural production systems to keep up with human population growth has led to innovations to manage pest populations - predominantly with chemical pesticides. For decades, a range of pesticides have reliably and efficiently controlled pest arthropods, weeds and diseases, and new chemistries continue to emerge. However, an over-reliance on chemical controls has escalated the emergence of chemical resistance across a range of pests to a variety of pesticides. ${ }^{1}$ The diminishing number of chemical options that remain effective against some key pests poses serious problems for the continued cost-effective protection of crops. ${ }^{2,3}$ Sustainable management of pesticides is challenging; the relatively short-term goals of local agri-business (sales and profit) and individual farmers (enhanced in-season 'insurance' and/or protection offered by one or multiple applications of relatively low-cost pesticides) often conflict with the community's and industry's broader goals (long-term stewardship of a shared-chemical resource through targeted pesticide applications and fewer chemicals in the environment).

Globally, there are more than 580 documented cases of arthropod pests evolving resistance, and 325 unique chemicals for which one or more species have evolved resistance. ${ }^{1}$ Resistance issues will inevitably continue to increase. This is despite the overall quantity of insecticides being used decreasing in many regions of the world. In the US, the quantity of insecticides applied in many food crops is lower than it was 20-30 years ago. ${ }^{4}$ In part this reduction has been influenced by the introduction of 
genetically modified crops ${ }^{4}$ which in turn has increased selection pressure for resistance to those toxins expressed in transgenic plants. The western corn rootworm (Diabrotica virgifera virgifera), for example, has evolved resistance to an insecticidal toxin derived from the bacterium Bacillus thuringiensis (Bt) after consecutive plantings of the same type of transgenic maize. ${ }^{5}$ In the EU, recent moves towards the sustainable use of pesticides is intended to result in a gradual decrease in insecticide use in several European countries ${ }^{6}$, and in theory minimize the selection of resistance. However, as pointed out in the 'Declaration of Ljubljana', this legislative change could have the adverse effect of increasing the risk of resistance evolution due to a diminished diversity of chemical options for farmers. ${ }^{7}$

Broad approaches to the management of resistance evolution have not fundamentally changed in decades, although new molecular, species-specific and chemical-specific research has been crucial in assisting management in local operational contexts. The speed at which resistance evolves is influenced by many factors including the rate of reproduction, migration and host range of the pest, proximity of susceptible populations, persistence and specificity of the insecticides used, and rate, timing and number of chemical applications. ${ }^{8}$ However, despite this awareness, early warnings and recommendations have been largely ignored, as short-term economic priorities at the individual-level continue to outweigh long-term sustainability and chemical stewardship goals.

This article is protected by copyright. All rights reserved. 
Insecticide resistance is increasingly attracting attention within large-scale cropping operations in Australia for a variety of reasons: chemicals continue to be applied prophylactically, ${ }^{9}$ placing high selection pressure for resistance on target pests; some older insecticide groups have been withdrawn by regulatory authorities and others are likely to follow, ${ }^{10}$ which increases reliance on the remaining chemistries; and perhaps most importantly, resistance issues are increasingly emerging, rendering some insecticides completely ineffective for particular pests of pastures, grain and horticultural crops. ${ }^{9,11,12}$ Australian farmers are increasingly grappling with resistance problems that threaten effective management of pests traditionally controlled using chemicals.

The Australian grain industry has several features that influence (and complicate) resistance management. Australia's climate contributes to arthropod pest outbreaks being variable, and profit margins being unpredictable and often low. Farms are large and production systems are highly mechanized across large fields. ${ }^{13}$ This situation is similar to the corn belt of the US, but differs from farming in many European and Asian countries where farms and fields tend to be smaller and climate more predictable. Both the marginality and scale of cropping means that regular crop monitoring for arthropods is perceived to be unaffordable, and farmers often resort to low cost 'insurance' sprays to reduce the short-term risk of pest incursions. As Australia is a net exporter of grain, trading standards are high and require very low thresholds of insect contamination or pest damaged grain, often resulting in a stronger 
emphasis on chemical control. Like a number of other counties (particularly those in the EU), Australia has a partial ban on transgenic crops that prevents farmers from accessing GMO food crops expressing insecticidal traits. If available, these would almost certainly reduce reliance on insecticide applications. ${ }^{14}$

In this paper, we review the status of insecticide resistance in Australian grain crops and provide a context for how resistance is currently managed. We discuss emerging technologies and new research, and then provide an overview of options to strategically manage resistance with a view to ensuring the long-term viability of control options available to the industry.

\section{Resistance status in Australian grains and industry trends}

\subsection{Resistance among arthropod grain pests}

A number of important arthropod pests of grain crops have evolved insecticide resistance in Australia. These include Helicoverpa armigera (cotton bollworm), Plutella xylostella (diamondback moth), Myzus persicae (green peach aphid) and Halotydeus destructor (redlegged earth mite). With the exception of H. destructor (a pest largely restricted to Australia and South Africa), these species are known to have resistance both in Australia and overseas (Table 1). Control of H. armigera, $P$. xylostella and $M$. persicae is complicated by widespread insecticide resistance across multiple chemical groups and different agricultural industries. ${ }^{12,15,16}$ This situation is similar to what is being observed in other countries. For example, M. persicae

This article is protected by copyright. All rights reserved. 
populations in Europe now possess resistances to a very large number of insecticide groups, which is hampering management efforts by farmers. ${ }^{17}$ For $H$. destructor, resistance is common in Western Australia, and has recently been detected in parts of eastern Australia. ${ }^{11,18}$ Other species considered minor pests of Australian grain crops that have evolved resistance include Bemisia tabaci (silverleaf whitefly), Tetranychus urticae (two spotted mite), Frankliniella occidentalis (western flower thrips) and Thrips tabaci (onion thrips) (Table 1), species that are important global pests.

$<<<$ insert Table $1>>>$

Given selection pressures are likely to remain high as a result of the ongoing reliance on insecticides in grain and other agricultural industries, it is expected that additional species will evolve resistance in the coming years. Understanding which species are at greater risk of evolving resistance is not straightforward. As a result of changes in farming practices, insecticide usage patterns and climate, the overall pest status of some species is likely to increase. In Australia, these include Sminthurus viridis (lucerne flea), Balaustium medicagoense (Balaustium mite) and Penthaleus spp. (blue oat mite), ${ }^{19}$ species that are major grain pests and frequently targeted with insecticides because they attack crops at the vulnerable seedling stage. ${ }^{20}$ Recent studies have shown difficulties already exist when attempting to control these pests due to inherent tolerance to certain chemicals. ${ }^{21-23}$ Sminthurus viridis for example, is sensitive to organophosphorus chemicals, but tolerant to pyrethroid chemicals. ${ }^{24}$ There are few

This article is protected by copyright. All rights reserved. 
registered chemical options available to control $S$. viridis and Australian farmers rely almost exclusively on organophosphates. ${ }^{29}$ This limits the rotational options (see Section 2.2), placing greater selection pressure for resistance on $S$. viridis. While species 'most at risk' of resistance evolution are difficult to confidently predict, useful methods have been developed to assess the likelihood of resistance evolving to fungicides $^{24,25}$ and insecticides ${ }^{26}$ (also see Section 3.2). Similar approaches are starting to be applied to Australian grain pests (Maino, J. unpubl. data) (see also Section 3.2).

\subsection{Insecticide trends in Australian grain systems}

Despite the heavy reliance on chemicals for pest control in Australian grain crops, there is no coordinated database of agrichemical use in Australia (unlike in many other parts of the world). Market research data, typically undertaken by individual companies, is often the best means by which to understand crop protection chemical usage patterns. In Australia, there are few unique chemical modes of action (MoA) among the insecticides registered for a given pest and crop combination (Table 1). Moreover, the grains industry is heavily reliant on Group 1 (carbamates 1A and organophosphates 1B), Group 3A (pyrethroids) and Group 4A (neonicotinoids) insecticides (Figure 1). This is analogous to the US, where organophosphates, carbamates, neonicotinoids and pyrethroids made up $>75 \%$ of the total insecticide usage (total $\mathrm{kg}$ ) between $2009-2016^{27}$ and is also broadly consistent with global insecticide usage patterns. ${ }^{1}$ In Australia, the older and less expensive chemistries (i.e. 
organophosphates, pyrethroids) are extensively used in cereal, legume and rape crops. This is particularly the case for cereals (wheat, barley, oats, rye and triticale), with organophosphates and pyrethroids accounting for $>85 \%$ of all estimated insecticide applications (Figure 1A). In legumes, the picture is similar, although pyrethroids are by far the most widely used MoA (Figure 1B). Neonicotinoids are used far less than in cereals. Pyrethroids, organophosphates and neonicotinoids are widely applied in rape crops within Australia. Other MoAs, such as sulfoxomines (Group 4C) and fiproles (Group 2B), are applied less frequently (Figure 1C). When all agricultural crops are considered together, the pattern of insecticide usage differs considerably. While pyrethroids, organophosphates and neonicotinoids remain the most commonly applied chemicals in Australia, there is much greater diversity and spread across MoA groups (Figure 1D). This is not surprising given the higher economic value of most non-grain crops (i.e. vegetables, citrus, potatoes, tropical fruits, rice, sugar cane, cotton and grapes), allowing more expensive insecticidal formulations (e.g. Bt (Group 11A), spinosyns (Group 5), diamides (Group 28) and oils) to be applied in these crops.

$<<<$ insert Figure $1>>>$

A different spectrum of insecticides is used to control various grains pests in Australia, including those for which insecticide resistance is already present. For $M$. persicae, H. armigera and $P$. xylostella, a large number of MoAs are registered in 
Australia (Table 1) and a wide variety of MoAs are applied by farmers (Figure 2). This likely reflects the global status of these pests (and thus greater investment from agrichemical companies towards $R \& D$ ) and the diversity of agricultural commodities each of these species attack. ${ }^{16,28,29}$ For $H$. destructor however, the story is very different. Only four unique MoAs are registered against this pest (Table 1). Of these, farmers are heavily reliant on only three: organophosphates, pyrethroids and neonicotinoids (Figure 2B). Given neonicotinoids are only registered as seed dressings against $H$. destructor, this considerably hinders rotational options available for managing resistance.

$<<$ insert Figure $2>>>$

Globally, there has been a consistent increase in the number of chemical formulations registered in the last two decades, however the number of new active ingredients for many major classes of insecticides has increased at a far slower rate. ${ }^{30}$ This is also true in Australia (see Figure 3). For some grain pests (e.g. H. destructor), new insecticide formulations with unique MoAs have not been registered in more than 15 years. Given that the rotation of chemicals between MoA groups is one of the foundations of resistance mitigation, the limited options of unique chemical groups is a key obstacle for farmers. Although new insecticide formulations will no doubt be registered against grain pests in the future, the number of active ingredients with new 
MoAs entering the market will be limited due to the substantial development costs and increasing regulatory requirements.

$<<<$ insert Figure $3>>>$

Within Australia, insecticides are increasingly applied as mixtures of active ingredients to control grain pests, either through on-farm tank mixes or commercial co-formulated products (Figure 3). This trend is occurring elsewhere in the world, including the US and Europe. Currently, four co-formulations targeting arthropod pests are registered in the Australian grain industry ${ }^{31}$ and more registrations are likely. Insecticide mixtures offer a range of potential benefits. They may provide improved control of pests through synergistic interactions or through potentiation, they may be effective when partial resistance has evolved ${ }^{32}$ and can help target multiple life stages of pests (or a complex of pest species) when these differ in their susceptibility to different chemicals. If the chemicals within a mixture affect different target sites, the likelihood of two (or more) mutations being present simultaneously is extremely low and thus should reduce the rate at which resistance evolves. However, against this, there are various attributes of insecticide mixtures, such as differing decay rates, which may not only reduce the rate at which resistance evolves, but in some situations exacerbate the risk of resistance. ${ }^{33}$ Furthermore, mixtures can have synergistic toxic effects on beneficial arthropods that are greater than the effects of the active ingredients singly, ${ }^{33}$ which can lead to greater chemical use (due to the suppression of 
natural biological control), thus further increase selection pressure for resistance evolution.

In addition to insecticide mixtures, the last decade has seen a substantial increase in the adoption of insecticide seed dressings in Australia, particularly on rape. It is now difficult for farmers to commercially purchase rape seed that is not coated with an insecticide dressing. Seed dressings are also becoming more common on cereals, particularly in response to new threats such as the Russian wheat aphid (Diuraphis noxia), which was first detected in Australia in $2016 .{ }^{34}$ Seed dressings can be effective at curbing pest feeding damage and virus transmission in vulnerable establishing crops. In contrast to foliar sprays, they reduce the risk of chemical exposure to farmers and spray operators, and many beneficial arthropods. They can also reduce carbon emissions through a reduced need to apply foliar chemical sprays to control crop pests. However, the almost universal use of insecticide seed dressings in some crops will hasten the evolution of resistance, such as observed in tobacco thrips (Frankliniella fusca) in cotton fields in the US. ${ }^{35}$ Seed dressings used in Australian grain crops and elsewhere are by their very nature pre-emptive. The decision to use a seed dressing is typically made many months before sowing, well before the opportunity arises to assess the risk of most crop establishment pests. Within Australia, seed dressings mostly contain a neonicotinoid, limiting the opportunity to rotate with seed dressings containing different MoAs. ${ }^{31}$ Resistance of 
crop pests to neonicotinoids is already commonplace, reaching a level at which some major pests, such as $M$. persicae and B. tabaci, cannot be effectively controlled.

\subsection{Resistance management in Australian grains}

Insecticide resistance management strategies (IRMSs) aim to prevent or delay resistance evolving, or to help regain susceptibility in pest populations in which resistance has already arisen. Several IRMSs are currently used in Australia. The most widely adopted by farmers is the Cotton IRMS, which is regionally adapted and includes multiple pests. ${ }^{36}$ More recently, IRMSs have been developed specifically for the grain industry, but these are species-specific, covering $M$. persicae, H. destructor, P. xylostella and H. armigera (https://ipmguidelinesforgrains.com.au). Each of these strategies is underpinned by principles relating to the judicious use of insecticides: (1) only applying chemicals when the pest infestation warrants it; (2) avoiding the application of broad-spectrum formulations as much as practical; and (3) rotation of formulations whereby the same MoA is not applied across consecutive generations of the target pest. As with the Cotton IRMS, the new grain IRMSs also advocate integrated pest management (IPM) tactics, such as minimising the risk of pest buildup on weeds, strategic grazing of crops and pastures by livestock and, in the case of $H$. armigera, destroying pupae in the stubble of treated fields.

A key challenge facing the Australian grain industry is the adoption of these IRMSs. Similar to overseas experiences, there are considerable barriers preventing the wide- 
scale adoption of resistance management in Australia: (1) IRMSs are only available for a few species, and those that exist do not adequately consider the complexities when multiple pests are present; (2) there is tension between local management objectives (e.g. 'insurance' sprays) and those based on regional or industry priorities (e.g. reducing chemical applications to minimize resistance); (3) there have been limited institutional approaches to extend IRMSs to farmers, and (4) scientists often rely on imperfect knowledge when developing IRMSs, and thus the value of longterm strategies can be difficult to support with empirical data. And perhaps most importantly, resistance issues in Australia and overseas are often not perceived as a priority for farmers, given the complexity and immediacy of on-farm management decisions they face. As stated by Alyokhin et al. (2008) in relation to resistance management of the classic pest, the Colorado potato beetle (Leptinotarsa decemlineata), "Although there is general acknowledgment of the problem, dealing with it remains low on the average grower's list of priorities". ${ }^{37}$

\section{The future of resistance management in Australian grains}

The Australian Grains Research and Development Corporation (GRDC), together with entomologists and resistance experts, established a National Insecticide Resistance Management (NIRM) working group in 2013. NIRM has been responsible for: (1) developing IRMSs for key pests, focusing on species where resistance is present; (2) facilitating interactions with CropLife Australia and stakeholder feedback between agrichemical companies, scientists and farmers; and (3) providing

This article is protected by copyright. All rights reserved. 
connections with other agricultural industries facing insecticide resistance issues in Australia. The establishment of NIRM has been a valuable step forward and is a model worth instituting in other agricultural industries grappling with similar resistance issues. However, obstacles still exist, that prevent effective management of resistance. In Table 2 and below we outline some key elements necessary to overcome these obstacles in order to strategically manage resistance in Australian grain pests and help preserve the efficacy of important chemicals.

$<<<$ insert Table $2>>>$

\section{$\underline{3.1 \text { Baseline data and resistance monitoring programs }}$}

Before the introduction of any new MoA, it would be wise to define dose-response relationships for target pests, especially for species such as $M$. persicae and $P$. xylostella that have a high propensity to evolve insecticide resistance. New testing methodologies may need development as new formulations with unique chemistries are identified. Baseline sensitivity data should be generated for a representative collection of field populations that encompass the geographical spread of a pest and relevant cropping systems. The vast majority of new insecticide formulations currently entering the Australian market are introduced without the data needed to implement sound IRMSs (Table 2).

This article is protected by copyright. All rights reserved. 
Once insecticide baseline data are established, regular monitoring of field performance should be carried out, so the incidence, distribution and nature of resistance can be established and reduced through active management. Resistance monitoring efforts should not only target grain crops, but encompass other agricultural industries where the species in question are known to be pests. This is particularly important for pests where the intensity of selection pressure from insecticides is equivalent or greater in crops outside of the grain industry. Most horticultural crops in Australia, for example, receive on average, more insecticides per growing season than grain crops, and a handful of studies have revealed high gene flow in pests across horticultural and grain industries (e.g. de Little ${ }^{38}$ ). Where available, scientists should make use of genetic markers to aid monitoring programs. New genomic tools can greatly assist in monitoring programs aimed at understanding ongoing processes as new resistance alleles with different costs and inheritance patterns are discovered in treated populations. DNA-based tests have recently been implemented for resistance screening of $H$. destructor and $M$. persicae populations in Australia, ${ }^{12,39}$ and are used to screen for certain resistances in H. armigera. ${ }^{40}$ Surprisingly, similar tools have not been widely developed and utilized for routine resistance surveillance in P. xylostella and other important species in Australia, even though many resistance mechanisms have been identified. ${ }^{41}$ New molecular approaches (e.g. CRISPR) offer novel opportunities to identify resistance mechanisms that have previously proven difficult. ${ }^{42}$ 
National programs for insecticide resistance monitoring for major grain pests should be implemented as a matter of priority. Importantly, these programs should evaluate the proportion of susceptible individuals over time. These comparisons will help detect resistance alleles while at a low frequency in populations, when resistance management programs have a much greater chance of success. The value of such proactive programs is evidenced by the detection of Vip3A resistance alleles in $H$. armigera populations before the commercial release of transgenic cotton expressing the toxin. ${ }^{43}$

Because some arthropods are highly mobile, gene flow often occurs between populations in different countries, which can influence resistance patterns. Certain $M$. persicae resistance alleles have migrated to the UK from continental Europe. ${ }^{44}$ An 'Asian pyrethroid resistance allele' was recently detected in Australian populations of H. armigera (Edwards O, unpubl. data), while a recent incursion of $H$. armigera into Brazil included individuals with resistance to pyrethroids. ${ }^{45}$ The risk of incursions into Australia is likely to be lower than many other countries due to the strong quarantine and biosecurity system in place and Australia's island status. However, Australia's border is enormous, and there is a rapidly increasing movement of goods and people across it. The incursion of two very damaging pests, D. noxia and Bactericera cockerelli (tomato potato psyllid), in the last 2 years highlight the enormity of the challenge. For pests already established in a country, new resistances could be introduced through gaps in the quarantine system. A recent genetic study 
involving more than 170 Australian populations and 40 overseas populations of $M$. persicae (using 50 polymorphic microsatellite DNA markers) indicates resistant biotypes may have arrived in Australia from overseas, and quickly spread across the country (Weeks A, 2017, pers. comm.). Consequently, we suggest resistance monitoring of cosmopolitan pests should include international biotypes for benchmarking of global conspecifics.

\section{$\underline{3.2 \text { Modelling and risk analysis }}$}

An understanding of resistance risks can be enhanced through statistical models (identifying patterns in complex data sets) and computer simulation studies (simulating resistance outcomes under different selection or evolutionary scenarios). Both help to bring additional value to the monitoring and management programs described earlier (Table 2). For example, models can aid in identifying high-risk areas or practices for pre-emptive management. ${ }^{46}$ The evolution and management of insecticide resistance is multi-dimensional, and computational approaches help in making this complexity more manageable, and in identifying factors influencing resistance risk. $^{47}$

Large data sets on different chemical practices, land usage or climatic patterns can be incorporated into predictive models that test for statistical correlations between resistance and model inputs. An advantage of large-scale copping systems such as the Australian and US grain landscapes is that relatively coarse environmental data can be 
leveraged to gain insights into resistance risks (e.g. 5-km resolution data would be less relevant for horticulture). A technique commonly applied in machine learning was recently used to successfully capture the current distribution of insecticide resistance of $H$. destructor within Australia from environmental and management factors hypothesized to increase resistance risk. This modelling highlighted geographic locations without resistance, but with similar properties to areas with resistance. ${ }^{46}$ Since this study, resistant field populations have been detected within regions identified as high-risk (Figure 4), thus demonstrating the value of such approaches. Using a compiled data set on the biological traits of 902 arthropod species, $\operatorname{Hardy}^{26}$ identified strong associations between diet breath and voltinism, and the propensity of a pest to evolve resistance (as well as the number of MoA groups to which resistance has evolved). Such approaches not only help to explain how resistance might evolve, but can promote resistance management of high risk species before it evolves.

$<<<$ insert Figure $4>>>$

While statistical approaches can be useful for interpreting large and multidimensional data sets, a shortcoming of correlative approaches is that identified patterns may be spurious and form an unreliable basis for prediction, particularly when extrapolating to novel conditions. ${ }^{48}$ To address this issue, other modelling approaches (e.g. simulation studies) restrict predictions to 'realistic' values by 
incorporating detailed knowledge on how resistance evolves. Knowledge that can be incorporated includes the genetic basis of resistance, selection pressures acting on resistance alleles, costs associated with resistance, the mode of reproduction of species, or patterns of gene flow in pests that can dilute the effects of resistance or cause it to spread locally or from other industries. ${ }^{49-51}$ These models require a detailed understanding of the biology and ecology of the pest organism as well as the genetic basis of resistance within the local context and the origin of resistance. Unfortunately, genetic data is mostly unavailable for Australian grain pests and indeed most agricultural pests globally. Helicoverpa armigera is one of a few exceptions, where information has been available on costs and the genetic basis of resistance based on research efforts spanning multiple decades. ${ }^{15}$

\section{$\underline{3.3 \text { Greater adoption of IPM }}$}

In the Australian context, both crop scale and uncertain profitability contribute to the poor adoption of IPM, and a heavy reliance on broad-spectrum pesticides to 'insure' against or combat pest occurrences, particularly during crop establishment. ${ }^{13,20}$ However, the widescale adoption of IPM would go a long way towards minimizing and managing insecticide resistance. IPM employs a package of tactics to reduce pest pressures, and in grain crops can include cultural and agronomic practices that suppress pests (e.g. pre-crop grazing, multi layered shelterbelts, early sowing), the removal of alternate plant hosts and the use of pest monitoring practices and economic thresholds to guide chemical decision-making (Table 2). Combined, these 
approaches reduce farmers' reliance on insecticides for pest management. The impact of non-selective insecticide applications on beneficial arthropods and their compatibility with IPM also need to be considered. Predators and parasitoids can play an important role in resistance management, especially when part of an established IPM program, as exemplified by $P$. xylostella management in Australian rape crops. ${ }^{16}$ If farmers were able to rely more on beneficial arthropods, fewer insecticide applications would be needed, reducing selection pressures. The success of the Australian cotton IRMS has in part been realized through increased reliance by farmers on biological control. ${ }^{36}$ Beneficial arthropods are encouraged through decreasing the frequency of insecticide applications and increasing their selectivity, as well as providing refuge habitat (e.g. remnant vegetation, windbreaks) and alternate food sources (e.g. nectar sources, non-pest hosts). ${ }^{52}$ There are critical knowledge gaps in Australian grain systems for implementing such an approach (Table 2). Of course, these obstacles are almost ubiquitous across all developed countries. In the developing world, successful adoption of IPM is further impeded by resource-poor farmers which are typically supported by insufficient training, and weak extension agencies and networks. ${ }^{53}$

The use of broad-spectrum insecticides disrupts biological control through direct toxicity to beneficial species, and indirectly by changing arthropod communities. While insecticide seed dressings are now widely used in grains, and have less pervasive effects on beneficial organisms than conventional high-volume sprays, they 
can still adversely impact arthropod predator and parasitoid communities. ${ }^{54,55}$ This is an important issue given the scale at which these insecticides are now being applied. Outside of beneficial arthropods, a lack of economic thresholds for key pests is a major constraint to the adoption of IPM in Australian grain crops and elsewhere. In part, this leads to indecision and the prophylactic application of insecticides potentially increasing the risk of resistance. The risk is dependent on numerous factors such as the genetic basis of resistance across field doses, the starting resistance allele frequencies and pest dispersal rates. ${ }^{56}$ Thresholds help to rationalize the use of insecticides and are a fundamental tenet underpinning IPM practices, ${ }^{57}$ assuming they are accurate and appropriately applied. A recent review commissioned by the GRDC identified numerous gaps in economic thresholds available within the Australian grain industry (Miles M, 2018, pers. comm.). For most pests, there are either no economic thresholds or those that do exist are only regionally relevant and/or nominal (i.e. subjective, without an empirical basis). Thresholds are deemed appropriate for at least 35 major pest group/crop combinations in grains, but a dynamic threshold is available for only one species (H. armigera), with none that account for the impact of beneficial organisms suppressing the pest (Miles M, 2018, pers. comm.). This paucity of dynamic thresholds, which can take years of research to develop for a single pest, is common for most crops around the world. ${ }^{58}$ 


\subsection{Embracing emerging technologies}

Molecular technologies present novel solutions to previously intractable problems in resistance management and some of these have application to Australian grain pests. For example, CRISPR technology could be deployed to modify the genome of pests and, using a natural or synthetic gene drive mechanism ${ }^{59}$, drive susceptible alleles back into resistant populations. Helicoverpa armigera would be a strong candidate because many simple resistance mutations to $B t$ toxins have already been identified, ${ }^{60}$ and this approach could be integrated into an existing resistance management program. ${ }^{40}$ Also, CRISPR-based editing of a $B t$ resistance allele has already been achieved in this species ${ }^{61}$ and more recently, used to reverse engineer susceptibility to two different insecticide groups by targeting cytochrome P450 monooxygenases. ${ }^{42}$ Another potential application is to edit insecticide target site genes into important beneficial arthropods to make them tolerant to insecticides (and hence not be disrupted by applications against target pests), however, potential unintended ecological consequences (e.g. intraguild predation) would need to be carefully considered before such an approach was attempted. Insecticide-resistant natural enemies generated through laboratory selection have been used safely and successfully as part of IPM programs in the past. $^{62}$

A more contained method to drive down resistance alleles is the sterile insect technique, SIT. ${ }^{59}$ Recent modelling indicates the mass release of a male selecting strain of $P$. xylostella carrying insecticide susceptible alleles can effectively drive 
susceptibility into target populations. ${ }^{63}$ The challenge of this approach is the cost of producing sufficient numbers of released males to affect target populations, particularly in large broad-acre fields. Recent developments in robotics and automation could help to address this issue, but the costs of diet reagents might still be prohibitive. Using new sensors and big data analysis to quantify pests and/or injury to plants could help to alleviate the time constraints of crop monitoring necessary in IPM. ${ }^{58}$ Transgenic crops represent another opportunity to improve the way a number of grain pests are managed. The introduction of transgenic crops expressing insecticidal properties has transformed global agriculture, with their adoption continuing to grow annually. Like many other countries however, Australia has only seen the commercialisation of insect tolerant cotton; ${ }^{36}$ and there are currently no insecticidal transgenic food crops grown commercially. The potential benefits to resistance management, as observed in other systems, ${ }^{64}$ could be realized if host plant resistance is introduced to crops, such as oilseeds, pulses, cereals and sorghum. Helicoverpa armigera and P. xylostella would be obvious targets in grain crops expressing $B t$ toxins, while virus resistant traits, similar to those deployed in other systems, ${ }^{65}$ would result in significant reductions in insecticide sprays against species like M. persicae.

\section{$\underline{3.5 \text { Policy and market drivers for change }}$}

The need for wider IPM implementation in Australia has not yet made the political agenda. Recent experience in the EU provides an example of a policy intervention 
driven by a commitment to public health concerns and market access issues that has changed the way pesticides are licensed, produced and used, ${ }^{6}$ and emphasized IPM principles. ${ }^{66}$ However, it may have had some unexpected consequences. Selection for insecticide resistance might be expected to decline as IPM is progressively implemented, although in the EU (under related legislation ${ }^{67}$ ), fewer MoAs now available may counter any gains towards minimizing selection pressure. Additionally, the recent ban on neonicotinoids has likely increased use of older insecticides. ${ }^{68}$ In Australia, any government policy that enhances IPM implementation will only occur as part of a broader policy thrust. ${ }^{69}$ The most likely regulatory intervention pathway is through the Australian Pesticides and Veterinary Medicines Authority (APVMA), which may gradually withdraw some older insecticide chemistries in line with the EU and other OECD countries. However, unlike in the EU, a key driver is likely to be demands of export markets for low arthropod and chemical residues in grain. While this could encourage IPM adoption through the withdrawal of some broad-spectrum insecticides and indirectly making biological insecticide sprays (e.g. Bt and NPV) more cost competitive, it may also limit MoA rotation options for managing resistance to newer chemistries. In the US, there is a long-established program (the IR-4 Project) that facilitates the registration of formulations in minor crops to overcome a longstanding problem of limited chemical options in those commodities with a market share that is too small to justify the expense of chemical registration. ${ }^{70}$ A similar initiative has been launched in Australia (http://www.agriculture.gov.au/agfarm-food/ag-vet-chemicals/improved-access-agvet-chemicals) and could lead to 
more diverse MoAs being applied to facilitate resistance management programs; however, if not managed carefully, new registrations could increase the use of already popular (and commonly-used) chemicals. We advocate an extension of these programs that involves incentives to agrichemical companies for implementing stewardship practices around insecticide resistance, as was recently proposed for herbicides. $^{71}$

\subsection{Cross industry considerations}

Insecticide resistance in Australia appears more likely in polyphagous arthropods ${ }^{72}$ that are pests across multiple agricultural industries (grains, cotton, horticulture and pastures) (see Table 1) and move freely between them. Resistance management strategies need to account for differing selection pressures across industries both in terms of the intensity of selection and timing. Because of commercial sensitivity, agrichemical companies do not provide the relative quantities of chemicals being applied to pests across crops, making it hard to model relative selection pressures. This is further complicated by the fact that insecticide formulations registered for particular pests can vary between industries. Current resistance management strategies are industry-focussed, but overall selection pressure for resistance to any MoA is unlikely to decline if the same chemical continues to be used in an unrestricted way in another industry.

This article is protected by copyright. All rights reserved. 
Although this threat is widely appreciated across Australia's agricultural industries, there are no formal or integrated processes for collaboration. Greater cross-industry collaboration for successful stewardship of resistance management in Australia is needed and should involve stakeholders such as farmers (following labels, rotating chemicals), CropLife Australia and agrichemical companies (advocacy, stewardship of chemicals), funding organizations and research scientists (resistance monitoring, developing IPM strategies), and government extension staff and farm advisors (advocacy, providing advice) (Table 2).

\section{$\underline{3.7 \text { Communication and extension }}$}

The success of any IRMS is contingent on consistently applying the principles of the strategy, and yet the uptake of these principles remains relatively low among Australian grain farmers. ${ }^{73}$ To achieve greater IRMS uptake, a structured communication and extension effort is needed. This challenge is not easily resolved. Numerous barriers (and drivers) influence the uptake of resistance management guidelines, such as knowledge (e.g. economic thresholds), economic (e.g. cheap alternatives) and social (e.g. prior perceptions, uncertainty, peer pressure, decision making complexity) factors. ${ }^{73}$ While knowledge and economic factors are undoubtedly important and well publicized, social factors play a profound and often discrete role in farmer decisions regarding pest management decisions. ${ }^{74}$ This social dimension is not well understood in the Australian grain industry and is also an issue elsewhere. ${ }^{75}$ A long-term, structured and tailored plan is required to facilitate and 
evaluate practice change. For example, resistance guidelines might be better packaged as part of an overall IPM program rather than communicating IRMSs as discrete plans, leaving the integration into existing management approaches up to the individual farmer (or farm advisor). Lessons can be gleaned from the Australian cotton industry, which has an IMRS that is communicated through a fully integrated and enduring 'one-stop-shop' web and training resource, coordinated by a consortium of research scientists, extension specialists, agronomists and agrichemical company representatives. $^{36}$

Effective management of resistance will also require a coordinated effort to monitor changes in chemical use patterns driven by the IRMSs. Changes can only be monitored if chemical usage information is readily available, but this represents a current gap. The EU and OECD provide methodologies for collecting pesticide usage statistics, ${ }^{76}$ but these are expensive and onerous. Company-based databases capture large-scale chemical use information, mostly through farm management software, but the generated data are not widely accessible, analyzed seasonally or linked to practice change. A national database of agrichemical usage that provides information across regions and sorted by crop and target pest is required. This information would indicate selection pressures for target pests and whether there is practical change in response to IRMSs. Such a database would also considerably improve the ability to assess future resistance threats. 


\section{Conclusions}

Insecticide resistance challenges are increasing globally. Within the Australian grains industry, this is highlighted by the recent emergence of resistance in H. destructor, $M$. persicae and $P$. xylostella as well as ongoing problems with resistance in $B$. tabaci and $H$. armigera. At present, resistance issues are dealt with in a mostly reactive manner once resistance has arisen rather than proactively. This makes the industry dependent on new chemistries or transformational technologies. With a proactive approach, the risk of resistance evolving in the first place can be minimized by reducing selection pressures while suppressing pest populations. Multiple tactics for managing pests through IPM programs will reduce exposure to insecticides. A proactive, integrated approach should include:

(1) Identifying risk. Progress is needed in identifying pests likely to evolve resistance in the future, as well as understanding regional factors that reduce selection pressures. (2) Resistance management. Once resistance evolves, strategies need to be widely and consistently adopted to ensure resistances remain localized. An industry-wide and cross industry initiative can minimise spread across regions and between industries. (3) Socio-political initiatives. Policy reforms and/or incentive programs that enforce and promote management changes across agricultural industries will significantly reduce selection pressures.

These are important components in all resistance management programs that target not only insecticides but also herbicides and fungicides. ${ }^{75}$

This article is protected by copyright. All rights reserved. 


\section{Acknowledgements}

Thanks to members of NIRM, GPAC and others who have contributed ideas and discussion papers that form part of this manuscript, and the GRDC who have supported much of our resistance research. We would like to acknowledge Melina Miles and Nancy Schellhorn for comments and earlier contributions, as well as several anonymous reviewers and the editorial team. Thanks to Bayer CropScience for kindly sharing Australian insecticide market research data and assistance with interpretation. Thanks also to Elia Pirtle and Frances Morell for technical assistance.

This article is protected by copyright. All rights reserved. 


\section{References}

1 Sparks TC and Nauen R, IRAC: Mode of action classification and insecticide resistance management, Pestic Biochem Physiol 121: 122-128 (2015).

2 Whalon ME, Mota-Sanchez D, and Hollingworth RM, Analysis of global pesticide resistance in arthropds, In Global pesticide resistance in arthropods, ed. by Whalon ME, Mota-Sanchez D, and Hollingworth RM, Cornwell Press, Trowbridge pp. 5-31 (2008).

3 Cloyd RA, Western flower thrips (Thysanoptera: Thripidae) and insecticide resistance: An overview and strategies to mitigate insecticide resistance development, J Entomol Sci 51: 257-273 (2016).

4 Osteen CD and Fernandez-Cornejo J, Economic and policy issues of U.S. agricultural pesticide use trends, Pest Manag Sci 69: 1001-1025 (2013).

5 Gassmann AJ, Petzold-Maxwell JL, Keweshan RS, and Dunbar MW, Fieldevolved resistance to Bt maize by Western corn rootworm, PLoS One 6 (2011).

6 European Union, Directive 2009/128/EC of the European parliament and of the council of 21 October 2009 establishing a framework for community action to achieve the sustainable use of pesticides, Off J Eur Union 52: 71-86 (2009).

7 Bielza P, Denholm I, Loannidis P, Sterk G, Leadbeater A, Leonard P, et al., The impact of a declining European pesticide portfolio on resistance management, Outlooks Pest Manag 19: 246-248 (2008).

8 Roush RT and Tabashnik BE, Pesticide resistance in arthropods, Springer Science \& Business Media, Berlin (1990).

9 Downes S and Mahon R, Evolution, ecology and management of resistance in Helicoverpa spp. to Bt cotton in Australia, J Invertebr Pathol 110: 281-286 (2012).

10 APVMA, Omethoate: Regulatory Decisions, 2016. https://apvma.gov.au/node/20151 [accessed 12 April 2018].

11 Umina PA, Weeks AR, Roberts J, Jenkins S, Mangano GP, Lord A, et al., The current status of pesticide resistance in Australian populations of the redlegged earth mite (Halotydeus destructor), Pest Manag Sci 68: 889-896 (2012).

This article is protected by copyright. All rights reserved. 
12 Umina P, Edwards O, Carson P, Van Rooyen A, and Anderson A, High levels of resistance to carbamate and pyrethroid chemicals widespread in Australian Myzus persicae (Hemiptera: Aphididae) populations, J Econ Entomol 107: 1626-1638 (2014).

13 Nash MA and Hoffmann AA, Effective invertebrate pest management in dryland cropping in southern Australia: the challenge of marginality, Crop Prot 42: 289-304 (2012).

14 Phipps RH and Park JR, Environmental benefits of genetically modified crops: Global and European perspectives on their ability to reduce pesticide use, $J$ Anim Feed Sci 11: 1-18 (2002).

15 Forrester NW, Cahill M, Bird LJ, and Layland JK, Management of pyrethroid and endosulfan resistance in Helicoverpa armigera (Lepidoptera, Noctuidae) in Australia, Bull Entomol Res: R1-132 (1993).

16 Furlong MJ, Spafford H, Ridland PM, Endersby NM, Edwards OR, Baker GJ, et al., Ecology of diamondback moth in Australian canola: Landscape perspectives and the implications for management, Aust J Exp Agric 48: 14941505 (2008).

17 Bass C, Puinean AM, Zimmer CT, Denholm I, Field LM, Foster SP, et al., The evolution of insecticide resistance in the peach potato aphid, Myzus persicae, Insect Biochem Mol Biol 51: 41-51 (2014).

18 Maino JL, Binns M, and Umina P, No longer a west-side story - Pesticide resistance discovered in the eastern range of a major Australian crop pest, Halotydeus destructor (Acari: Penthaleidae), Crop Pasture Sci 69: 216-221 (2018).

19 Hoffmann AA, Weeks AR, Nash MA, Mangano GP, and Umina PA, The changing status of invertebrate pests and the future of pest management in the Australian grains industry, Aust J Exp Agric 48: 1481-1493 (2008).

20 Micic S, Hoffmann AA, Strickland G, Weeks AR, Bellati J, Henry K, et al., Pests of germinating grain crops in southern Australia: An overview of their biology and management options, Aust J Exp Agric 48: 1560-1573 (2008).

This article is protected by copyright. All rights reserved. 
21 Umina PA and Hoffmann AA, Tolerance of cryptic species of blue oat mites (Penthaleus spp.) and the redlegged earth mite (Halotydeus destructor) to pesticides, Aust J Exp Agric 39: 621-628 (1999).

22 Roberts JMK, Umina PA, Hoffmann AA, and Weeks AR, The tolerance of the lucerne flea, Sminthurus viridis (Collembola: Sminthuridae), to currently registered pesticides in Australia, Aust J Entomol 48: 241-246 (2009).

23 Arthur AL, Hoffmann AA, Umina PA, and Weeks AR, Emerging pest mites of grains (Balaustium medicagoense and Bryobia sp.) show high levels of tolerance to currently registered pesticides, Aust J Exp Agric 48: 1126 (2008).

24 Kuck K and Russell P, FRAC: Combined resistance risk assessment, In Fungicide Resistance: are we winning the battle but losing the war?, ed by Bryson RJ, Burnett FJ, Foster V, Fraaije BA and Kennedy R, AAB Conference Proceedings, Aspects of Applied Biology 78, 3-10 (2006).

25 Grimmer MK, van den Bosch F k., Powers SJ, and Paveley ND, Fungicide resistance risk assessment based on traits associated with the rate of pathogen evolution, Pest Manag Sci 71: 207-215 (2015).

26 Hardy NB, Peterson DA, Ross L, and Rosenheim JA, Does a plant-eating insect's diet govern the evolution of insecticide resistance? Comparative tests of the pre-adaptation hypothesis, Evol Appl 11: 739-747 (2018).

27 U.S. Department of the Interior, Pesticide National Synthesis Project, 2018. https://water.usgs.gov/nawqa/pnsp/usage/maps/county-level/ [accessed 22 November 2018].

28 Umina P, Edwards O, Baker G, Downard P, Hoffmann A, McDonald G, et al., The science behind the Resistance Management Strategy for the green peach aphid (Myzus persicae) in Australian grains, Grains Research and Development Corporation, Canberra, Australia, p. 12 (2014).

29 Bird L, Miles M, Cornwell G, Umina P, McDonald G, Hoffmann A, et al., The science behind the Resistance Management Strategy for the Helicoverpa armigera in Australian grains, Grains Research and Development Corporation, Canberra, Australia, p. 26 (2018). 
30 Sparks TC and Lorsbach BA, Agrochemical discovery - building the next generation of insect control agents, In Advances in agrochemicals: Ion channels and G Protein-Coupled Receptors (GPCRs) as targets for pest control, ed. by Gross AD, Ozoe YO, and Coats JR, Oxford University Press, pp. 1-17 (2017).

31 APVMA, Public Chemical Registration Information System Search, 2018. https://portal.apvma.gov.au/pubcris [accessed 12 April 2018].

32 Ahmad M, Potentiation between pyrethroid and organophosphate insecticides in resistant field populations of cotton bollworm Helicoverpa armigera (Lepidoptera: Noctuidae) in Pakistan, Pestic Biochem Physiol 91: 24-31 (2008).

33 Cloyd RA, Pesticide mixtures, In Pesticide mixtures, pesticides-formulations, effects, fate, ed. by Stoytcheva A, Intech, Croatia, pp. 69-80 (2011).

34 Yazdani M, Baker G, DeGraaf H, Henry K, Hill K, Kimber B, et al., First detection of Russian wheat aphid Diuraphis noxia Kurdjumov (Hemiptera: Aphididae) in Australia: a major threat to cereal production, Austral Entomol doi: 10.1111/aen.12292 (2018).

35 Huseth AS, Chappell TM, Langdon K, Morsello SC, Martin S, Greene JK, et al., Frankliniella fusca resistance to neonicotinoid insecticides: an emerging challenge for cotton pest management in the eastern United States, Pest Manag Sci 72: 1934-1945 (2016).

36 Wilson LJ, Whitehouse MEA, and Herron GA, The management of insect pests in Australian cotton: an evolving story, Ann Rev Entomol 63: 215-237 (2018).

37 Alyokhin A, Baker M, Mota-sanchez D, Dively G, and Grafius E, Colorado potato beetle resistance to insecticides, Am J Potato Res 6: 395-413 (2008).

38 de Little SC, Edwards O, van Rooyen AR, Weeks A, and Umina PA, Discovery of metabolic resistance to neonicotinoids in green peach aphids (Myzus persicae) in Australia, Pest Manag Sci 73: 1611-1617 (2017).

39 Edwards O, Walsh T, Metcalfe S, Tay T, Hoffmann A, Mangano P, et al., A 
genomic approach to understanding pyrethroid resistance in the redlegged earth mite, Halotydeus destructor, Pestic Biochem Physiol 144: 83-90 (2018).

40 Downes S, Mahon RJ, Rossiter L, Kauter G, Leven T, Fitt G, et al., Adaptive management of pest resistance by Helicoverpa species (Noctuidae) in Australia to the Cry2Ab Bt toxin in Bollgard II ${ }^{\circledR}$ cotton, Evol Appl 3:574-584 (2010).

41 Furlong MJ, Wright DJ, and Dosdall LM, Diamondback moth ecology and management: problems, progress, and prospects, Annu Rev Entomol 58: 517$541(2013)$.

42 Wang H, Shi Y, Wang L, Liu S, Wu S, Yang Y, et al., CYP6AE gene cluster knockout in Helicoverpa armigera reveals role in detoxification of phytochemicals and insecticides, Nat Commun 9: 4820 (2018).

43 Mahon RJ, Downes SJ, and James B, Vip3A resistance alleles exist at high levels in Australian targets before release of cotton expressing this toxin, PLoS One 7:e39192 (2012).

44 Fenton B, Malloch G, Woodford JT, Foster SP, Anstead J, Denholm I, et al., The attack of the clones: tracking the movement of insecticide-resistant peachpotato aphids Myzus persicae (Hemiptera: Aphididae), Bull Entomol Res 95: 483-494 (2005).

45 Tay WT, Walsh TK, Downes S, Anderson C, Jermiin LS, Wong TKF, et al., Mitochondrial DNA and trade data support multiple origins of Helicoverpa armigera (Lepidoptera, Noctuidae) in Brazil, Sci Reports 7: 45302 (2017).

46 Maino JL, Umina PA, and Hoffmann AA, Climate contributes to the evolution of pesticide resistance, Glob Ecol Biogeogr 27: 223-232 (2018).

47 Hackett SC and Bonsall MB, Type of fitness cost influences the rate of evolution of resistance to transgenic Bt crops, J Appl Ecol 53: 1391-1401 (2016).

48 Maino JL, Kong JD, Hoffmann AA, Barton MG, and Kearney MR, Mechanistic models for predicting insect responses to climate change, Curr Opin Insect Sci 17: 81-86 (2016).

49 Renton M, Shifting focus from the population to the individual as a way 
forward in understanding, predicting and managing the complexities of evolution of resistance to pesticides, Pest Manag Sci 69: 171-175 (2012).

50 Bourguet D, Delmotte F, Franck P, Guillemaud T, Reboud X, Vacher C, et al., The skill and style to model the evolution of resistance to pesticides and drugs, Evol Appl 3: 375-390 (2010).

51 Tabashnik BE, Computer Simulation as a Tool for Pesticide Resistance Management, In Pesticide Resistance: Strategies and Tactics for Management, ed. by National Research Council, National Academies Press, Washington, pp. 194-206 (1986).

52 Landis DA, Menalled FD, Costamagna AC, and Wilkinson TK, Manipulating plant resources to enhance beneficial arthropods in agricultural landscapes, Weed Sci 53: 902-908 (2005).

53 Parsa S, Morse S, Bonifacio A, Chancellor TCB, Condori B, Crespo-Pérez V, et al., Obstacles to integrated pest management adoption in developing countries, Proc Natl Acad Sci USA 111: 3889-3894 (2014).

54 Douglas MR and Tooker JF, Meta-analysis reveals that seed-applied neonicotinoids and pyrethroids have similar negative effects on abundance of arthropod natural enemies, PeerJ 4: e2776 (2016).

55 Douglas MR, Rohr JR, and Tooker JF, Neonicotinoid insecticide travels through a soil food chain, disrupting biological control of non-target pests and decreasing soya bean yield, J Appl Ecol 52: 250-260 (2015).

56 Takahashi D, Yamanaka T, Sudo M, and Andow DA, Is a larger refuge always better? Dispersal and dose in pesticide resistance evolution, Evolution 71: 1494-1503 (2017).

57 Brier HB, Murray DAH, Wilson LJ, Nicholas AH, Miles MM, Grundy PR, et al., An overview of integrated pest management (IPM) in north-eastern Australian grain farming systems: past, present and future prospects, Aust $J$ Exp Agric 48: 1574-1593 (2008).

58 Peterson RKD, Higley LG, and Pedigo LP, Whatever happened to IPM Am, Entomol 64:146-150 (2018).

This article is protected by copyright. All rights reserved. 
59 Scott MJ, Gould F, Lorenzen M, Grubbs N, Edwards O, and O’Brochta D, Agricultural production: assessment of the potential use of Cas9-mediated gene drive systems for agricultural pest control, J Responsible Innov 5:S98-S120 (2018).

60 Downes $\mathrm{S}$, Walsh T, and Tay WT, Bt resistance in Australian insect pest species, Curr Opin Insect Sci 15: 78-83 (2016).

61 Wang J, Wang H, Liu S, Liu L, Tay WT, Walsh TK, et al., CRISPR/Cas9 mediated genome editing of Helicoverpa armigera with mutations of an ABC transporter gene HaABCA2 confers resistance to Bacillus thuringiensis Cry2A toxins, Insect Biochem Mol Biol 87: 147-153 (2017).

62 Roush RT and Hoy MA, Laboratory, glasshouse, and field studies of artificially selected carbaryl resistance in Metaseiulus occidentalis, J Econ Entomol 74: 142-147 (1981).

63 Harvey-Samuel T, Morrison NI, Walker AS, Marubbi T, Yao J, Collins HL, et $a l .$, Pest control and resistance management through release of insects carrying a male-selecting transgene., BMC Biol 13: 49 (2015).

64 Knox OGG, Constable GA, Pyke B, and Gupta V, Environmental impact of conventional and $B t$ insecticidal cotton expressing one and two Cry genes in Australia., Aust J Agric Res 57: 501-509 (2006).

65 Ferreira SA, Pitz KY, Manshardt R, Zee F, Fitch M, and Gonsalves D, Virus coat protein transgenic papaya provides practical control of Papaya ringspot virus in Hawaii, Plant Dis 86: 101-105 (2002).

66 Barzman M, Bàrberi P, Nicholas A, Birch E, Boonekamp P, DachbrodtSaaydeh S, et al., Eight principles of integrated pest management, Agron Sustain Dev 35: 1199-1215 (2015).

67 Jess S, Kildea S, Moody A, Rennick G, Murchie AK, and Cooke LR, European Union policy on pesticides: implications for agriculture in Ireland, Pest Manag Sci 70: 1646-1654 (2014).

68 Carreck NL, A beekeeper's perspective on the neonicotinoid ban, Pest Manag Sci 73: 1295-1298 (2017).

This article is protected by copyright. All rights reserved. 
69 Foster J, Government policy strategies relating to the enhanced implementation of integrated pest management: a review, Aust J Environ Manag 2: 234-244 (1995).

70 US EPA, Questions and answers - exclusive use data protection for minor use registrations, EPA office of pesticide programs, US, p. 14 (2014).

71 Powles SB and Gaines TA, Exploring the potential for a regulatory change to encourage diversity in herbicide use, Weed Sci 64: 649-654 (2016).

72 Rane R V, Walsh TK, Pearce SL, Jermiin LS, Gordon KH, Richards S, et al., Are feeding preferences and insecticide resistance associated with the size of detoxifying enzyme families in insect herbivores?, Curr Opin Insect Sci 13: 70-76 (2016).

73 Grains Pest Advisory Committee, A status report on insecticide resistance in Australia, 2016. http://www.cesaraustralia.com/latestnews/sustainableagriculture/benchmarking-insecticide-resistance-in-australia [accessed 15 May 2018].

74 Ridgely AM and Brush SB, Social factors and selective technology adoption: the case of integrated pest management, Hum Organ 51: 367-378 (1992).

75 Gould F, Brown ZS, and Kuzma J, Wicked evolution: Can we address the sociobiological dilemma of pesticide resistance?, Science 360: 728-732 (2018).

76 European Commission, A common methodology for the collection of pesticide usage statistics within agriculture and horticulture, Office for Official Publications of the European Communities, Luxembourg (2008).

77 Baker G, Umina P, Miles M, Schellhorn N, Hoffmann A, Edwards O, et al., The science behind the Resistance Management Strategy for diamondback moth (Plutella xylostella) in Australian canola crops, Grains Research and Development Corporation, Canberra, Australia, p. 22 (2017).

78 Umina P, Hoffmann A, McDonald G, Edwards O, Mangano P, Miles M, et al., The science behind the Resistance Management Strategy for the redlegged earth mites (Halotydeus destructor) in Australian grains and pastures, Grains Research and Development Corporation, Canberra, Australia, p. 15 (2016). 
79 de Barro PJ, Bemisia tabaci biotype B: a review of its biology, distribution and control. Second edition, CSIRO Aust Div Entomol Tech Pap, CSIRO Division of Entomology, Canberra, Australia (1995).

80 Herron GA, James TM, Rophail J, and Mo J, Australian populations of onion thrips, Thrips tabaci Lindeman (Thysanoptera: Thripidae), are resistant to some insecticides used for their control, Aust J Entomol 47: 361-364 (2008).

81 Herron GA, Langfield BJ, Tomlinson TM, and Mo J, Dose-response testing of Australian populations of onion thrips Thrips tabaci Lindeman (Thysanoptera: Thripidae) further refines baseline data and detects methidathion and likely imidacloprid resistance, Aust J Entomol 50: 418-423 (2011).

82 Manners A, Managing two-spotted mite in production nurseries, Queensland depratment of Agriculture, Fisheries and Forestry, Brisbane, Australia p. 10 (2015).

83 Herron GA, Woolley LK, Langfield KL, and Chen Y, First detection of etoxazole resistance in Australian two-spotted mite Tetranychus urticae Koch (Acarina: Tetranychidae) via bioassay and DNA methods, Austral Entomol 57: 365-368 (2018).

84 Herron GA and Rophail J, First detection of chlorfenapyr (Secure $\left.{ }^{\circledR}\right)$ resistance in two-spotted spider mite (Acari: Tetranychidae) from nectarines in an Australian orchard, Exp Appl Acarol 31: 131-134 (2003).

85 Unwin B, Chemical resistance in populations of Tetranychus urticae (Koch) (Acarina: Tetranychidae) from apple orchards in New South Wales, Australia, J Aust Ent Soc 12: 59-67 (1973).

This article is protected by copyright. All rights reserved. 
Table 1. Arthropod species that are economically important pests of Australian grain crops and known to have field resistance

\begin{tabular}{|c|c|c|c|c|c|c|}
\hline Species name & Common name & Australian distribution & $\begin{array}{l}\text { Major agricultural } \\
\text { industries impacted }\end{array}$ & $\begin{array}{l}\text { No. insecticide MoAs } \\
\text { registered in Australia }\end{array}$ & $\begin{array}{l}\text { Documented cases of } \\
\text { resistance in Australia }\end{array}$ & References \\
\hline $\begin{array}{l}\text { Helicoverpa } \\
\text { armigera }\end{array}$ & $\begin{array}{l}\text { Cotton } \\
\text { bollworm }\end{array}$ & $\begin{array}{l}\text { Widespread; most common } \\
\text { in north-eastern Australia }\end{array}$ & $\begin{array}{l}\text { Cotton, grains, } \\
\text { horticulture }\end{array}$ & 8 & $\begin{array}{l}1 \mathrm{~A}, 1 \mathrm{~B}, 3 \mathrm{~A}, 5,11 \mathrm{C}, 22 \mathrm{~A}, \\
28\end{array}$ & 29 \\
\hline $\begin{array}{l}\text { Plutella } \\
\text { xylostella }\end{array}$ & $\begin{array}{l}\text { Diamondback } \\
\text { moth }\end{array}$ & $\begin{array}{l}\text { Widespread; most common } \\
\text { in southern regions }\end{array}$ & $\begin{array}{l}\text { Horticulture, grains, } \\
\text { forage }\end{array}$ & 11 & $1 \mathrm{~A}, 1 \mathrm{~B}, 3 \mathrm{~A}, 5,6,22 \mathrm{~A}, 28$ & 77 \\
\hline $\begin{array}{l}\text { Myzus } \\
\text { persicae }\end{array}$ & $\begin{array}{l}\text { Green peach } \\
\text { aphid }\end{array}$ & Widespread & $\begin{array}{l}\text { Horticulture, grains, } \\
\text { forage }\end{array}$ & 9 & $1 \mathrm{~A}, 1 \mathrm{~B}, 3 \mathrm{~A}, 4 \mathrm{~A}$ & 28,38 \\
\hline $\begin{array}{l}\text { Halotydeus } \\
\text { destructor }\end{array}$ & $\begin{array}{l}\text { Redlegged earth } \\
\text { mite }\end{array}$ & $\begin{array}{l}\text { Restricted to southern } \\
\text { Australia }\end{array}$ & Grains, pastures & 4 & $1 \mathrm{~B}, 3 \mathrm{~A}$ & 78 \\
\hline Bemisia tabaci & $\begin{array}{l}\text { Silverleaf } \\
\text { whitefly }\end{array}$ & $\begin{array}{l}\text { Widespread; most common } \\
\text { in northern regions }\end{array}$ & $\begin{array}{l}\text { Cotton, grains, } \\
\text { horticulture }\end{array}$ & 11 & $1 \mathrm{~A}, 1 \mathrm{~B}, 3 \mathrm{~A}, 4 \mathrm{~A}, 7 \mathrm{C}, 16$ & \begin{tabular}{|l|l|}
73,79 \\
\end{tabular} \\
\hline $\begin{array}{l}\text { Frankliniella } \\
\text { occidentalis }\end{array}$ & $\begin{array}{l}\text { Western flower } \\
\text { thrip }\end{array}$ & Widespread & Cotton, horticulture & 6 & $1 \mathrm{~A}, 1 \mathrm{~B}, 3 \mathrm{~A}, 4 \mathrm{~A}, 5$ & 3,73 \\
\hline Thrips tabaci & Onion thrip & Widespread & Horticulture, grains & 6 & $1 \mathrm{~B}, 3 \mathrm{~A}, 4 \mathrm{~A}$ & 80,81 \\
\hline $\begin{array}{l}\text { Tetranychus } \\
\text { urticae }\end{array}$ & $\begin{array}{l}\text { Two spotted } \\
\text { mite }\end{array}$ & Widespread & $\begin{array}{l}\text { Cotton, grains, } \\
\text { horticulture }\end{array}$ & 13 & $\begin{array}{l}1 \mathrm{~B}, 3 \mathrm{~A}, 10 \mathrm{~A}, 10 \mathrm{~B}, 12 \mathrm{~B} \\
12 \mathrm{C}, 12 \mathrm{D}, 13,21 \mathrm{~A}, \mathrm{UN}^{\ddagger}\end{array}$ & $82-85$ \\
\hline
\end{tabular}

${ }^{\dagger}$ IRAC chemical Mode of Action sub-groups. Does not include registered chemicals which are not listed in the IRAC classification (e.g. paraffinic oils). Source: APVMA, 2018.

${ }^{\ddagger}$ Dicofol has unknown Mode of Action classification (UN).

This article is protected by copyright. All rights reserved. 
Table 2. Suggested practices within the Australian grains industry and interventions to more strategically manage insecticide resistance

\begin{tabular}{|c|c|c|c|c|c|c|c|c|}
\hline & \multicolumn{2}{|c|}{ Industry practices } & \multicolumn{6}{|c|}{ On-farm pest management practices } \\
\hline & $\begin{array}{l}\text { Industry } \\
\text { awareness and } \\
\text { engagement in } \\
\text { resistance }\end{array}$ & $\begin{array}{l}\text { Knowledge of } \\
\text { resistance risks }\end{array}$ & $\begin{array}{l}\text { Proactive pest } \\
\text { management }\end{array}$ & $\begin{array}{l}\text { Pest } \\
\text { monitoring }\end{array}$ & $\begin{array}{l}\text { Economic } \\
\text { thresholds for } \\
\text { pests }\end{array}$ & $\begin{array}{l}\text { Beneficial } \\
\text { organisms }\end{array}$ & Insecticide choice & $\begin{array}{l}\text { MoAs available } \\
\text { and applied } \\
\text { strategically }\end{array}$ \\
\hline $\begin{array}{l}\text { Common } \\
\text { practice }\end{array}$ & $\begin{array}{l}\text { Little cross- } \\
\text { industry } \\
\text { collaboration. } \\
\text { Baseline } \\
\text { sensitivity data } \\
\text { generally not } \\
\text { available } \\
\end{array}$ & $\begin{array}{l}\text { Poor knowledge } \\
\text { of risks for } \\
\text { many pests, } \\
\text { chemicals }\end{array}$ & $\begin{array}{l}\text { Occasional. } \\
\text { Regional } \\
\text { differences exist }\end{array}$ & $\begin{array}{l}\text { Occasional. } \\
\text { Often } \\
\text { perceived as } \\
\text { too labour } \\
\text { intensive }\end{array}$ & $\begin{array}{l}\text { Occasional. } \\
\text { Only a few } \\
\text { reliable } \\
\text { thresholds } \\
\text { available }\end{array}$ & $\begin{array}{l}\text { Underutilised } \\
\& \text { lack of } \\
\text { confidence in } \\
\text { their capacity }\end{array}$ & $\begin{array}{l}\text { Broad-spectrum } \\
\text { insecticides } \\
\text { widely used as } \\
\text { first management } \\
\text { tactic }\end{array}$ & $\begin{array}{l}\text { Occasionally } \\
\text { applied. Few } \\
\text { MoA options to } \\
\text { rotate }\end{array}$ \\
\hline $\begin{array}{l}\text { Optimal } \\
\text { practice }\end{array}$ & $\begin{array}{l}\text { Integrated } \\
\text { resistance } \\
\text { management } \\
\text { applied across } \\
\text { commodities. } \\
\text { Affordable tools } \\
\text { to rapidly test for } \\
\text { resistance }\end{array}$ & $\begin{array}{l}\text { Industry \& } \\
\text { farmers } \\
\text { understand risks } \\
\text { and implement } \\
\text { appropriate } \\
\text { resistance } \\
\text { management }\end{array}$ & $\begin{array}{l}\text { Pest populations } \\
\text { reduced ahead } \\
\text { of cropping } \\
\text { season using } \\
\text { diverse IPM } \\
\text { tactics }\end{array}$ & \begin{tabular}{|l} 
Farmers \\
respond to \\
spatial \& \\
temporal pest \\
threats in a \\
timely \\
manner
\end{tabular} & $\begin{array}{l}\text { Economic } \\
\text { thresholds } \\
\text { used widely to } \\
\text { inform } \\
\text { management } \\
\text { decisions }\end{array}$ & $\begin{array}{l}\text { Beneficials } \\
\text { better } \\
\text { understood, } \\
\text { monitored \& } \\
\text { utilised }\end{array}$ & $\begin{array}{l}\text { Cost-effective } \\
\text { selective } \\
\text { insecticides used } \\
\text { routinely }\end{array}$ & $\begin{array}{l}\text { A range of } \\
\text { MoAs available } \\
\& \text { rotated } \\
\text { strategically }^{\dagger}\end{array}$ \\
\hline Interventions & Cross-industry & Resistance & Greater & Emerging & RD\&E in & RD\&E to & Regulatory & Communication \\
\hline
\end{tabular}




\begin{tabular}{|c|c|c|c|c|c|c|c|c|}
\hline required & $\begin{array}{l}\text { investment } \\
\text { through national } \\
\text { initiatives }\end{array}$ & $\begin{array}{l}\text { monitoring \& } \\
\text { testing services. } \\
\text { Ecological \& } \\
\text { chemical data } \\
\text { available for } \\
\text { risk analyses }\end{array}$ & $\begin{array}{l}\text { incorporation of } \\
\text { emerging } \\
\text { technologies. } \\
\text { Communication } \\
\text { \& engagement }\end{array}$ & $\begin{array}{l}\text { technologies } \\
\text { to automate/ } \\
\text { simplify } \\
\text { monitoring }\end{array}$ & $\begin{array}{l}\text { economic } \\
\text { thresholds for } \\
\text { key pests }\end{array}$ & $\begin{array}{l}\text { improve IPM } \\
\text { options. } \\
\text { Policy } \\
\text { changes that } \\
\text { enhance IPM } \\
\text { adoption }\end{array}$ & $\begin{array}{l}\text { withdrawal of } \\
\text { older, broad- } \\
\text { spectrums \& } \\
\text { policy support for } \\
\text { cost-effective } \\
\text { selective } \\
\text { formulations }\end{array}$ & $\begin{array}{l}\text { \& engagement. } \\
\text { Increased } \\
\text { regulation to } \\
\text { support new } \\
\text { technologies }\end{array}$ \\
\hline
\end{tabular}

${ }^{\dagger}$ The mechanism of resistance is important for rotational strategies and resistance to different mechanisms needs to be genetically independent. For instance, if the same resistance mechanism of enhanced P450 metabolism acts across different MoAs, rotation of MoAs may not be effective. 
Escalating insecticide resistance in Australian grain pests: contributing factors, industry trends and management opportunities

P.A. Umina*, G. McDonald, J. Maino, O. Edwards and A.A. Hoffmann

A complex of factors has contributed to current trends in insecticide usage and resistance in the Australian grain industry. Emerging technologies and research offer new ways to advance resistance management.

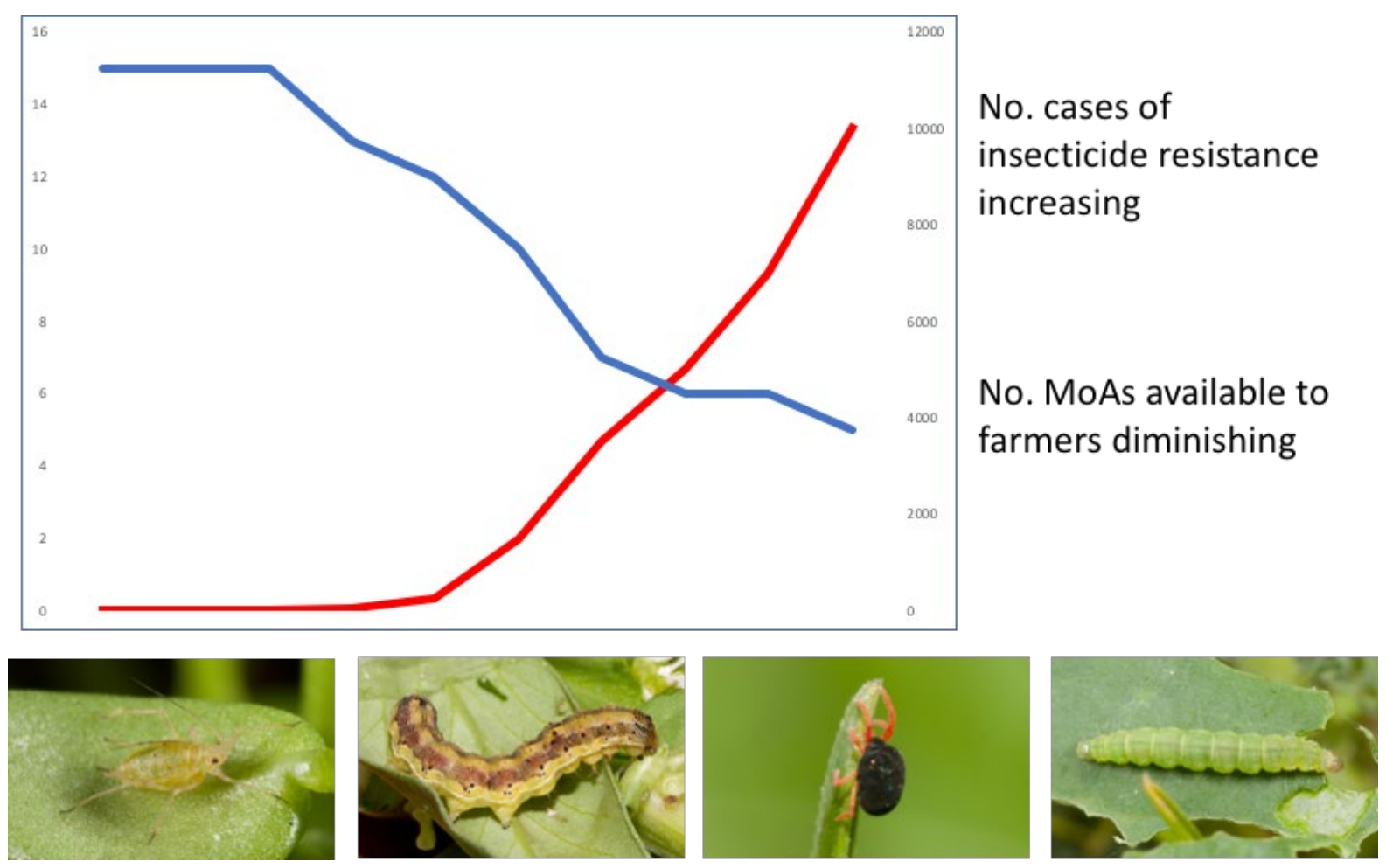

This article is protected by copyright. All rights reserved. 


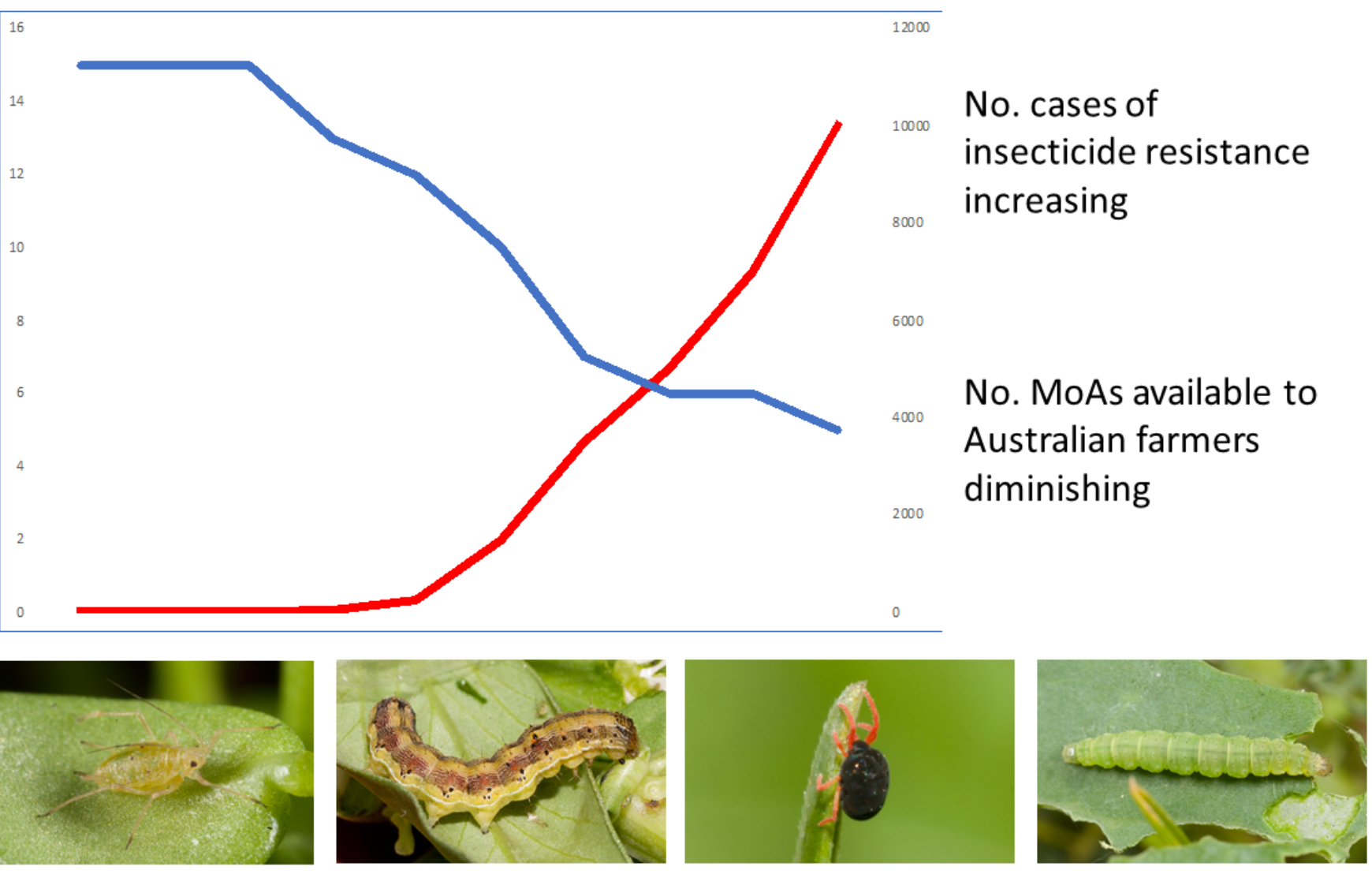

This article is protected by copyright. All rights reserved. 
A

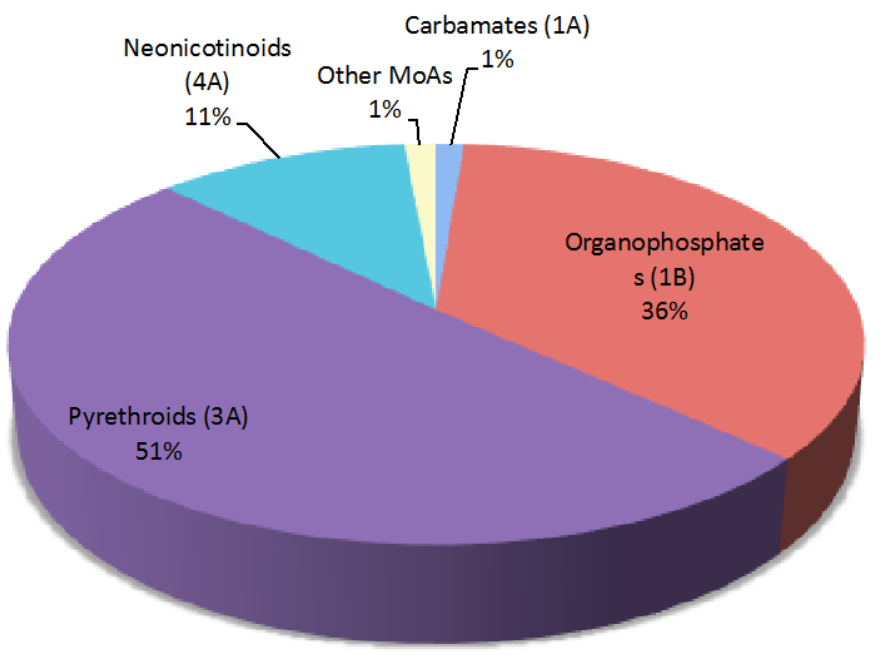

C

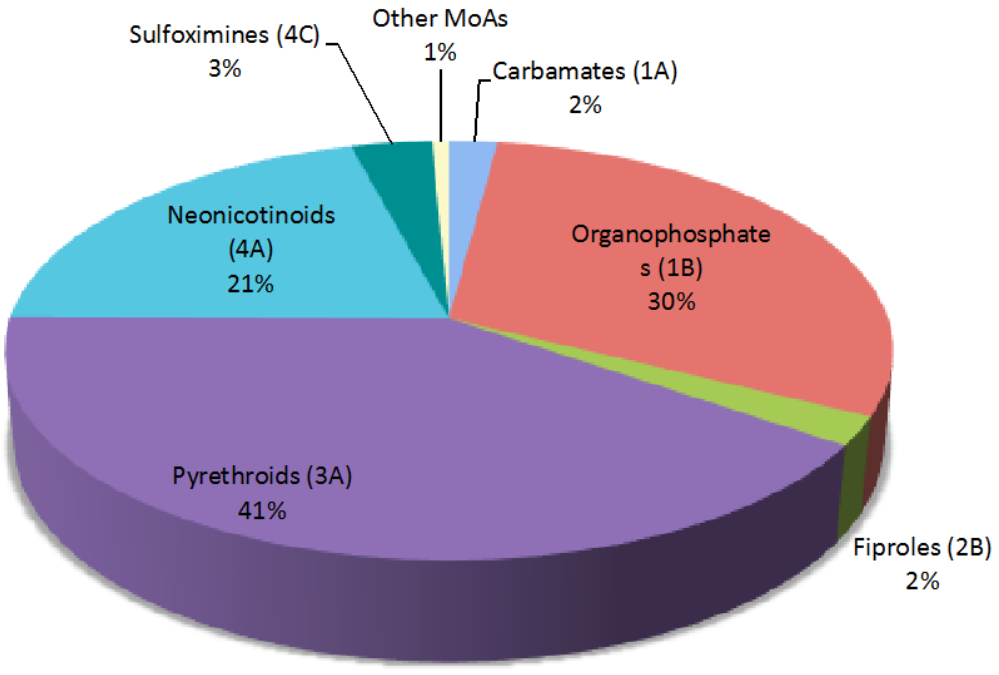

B
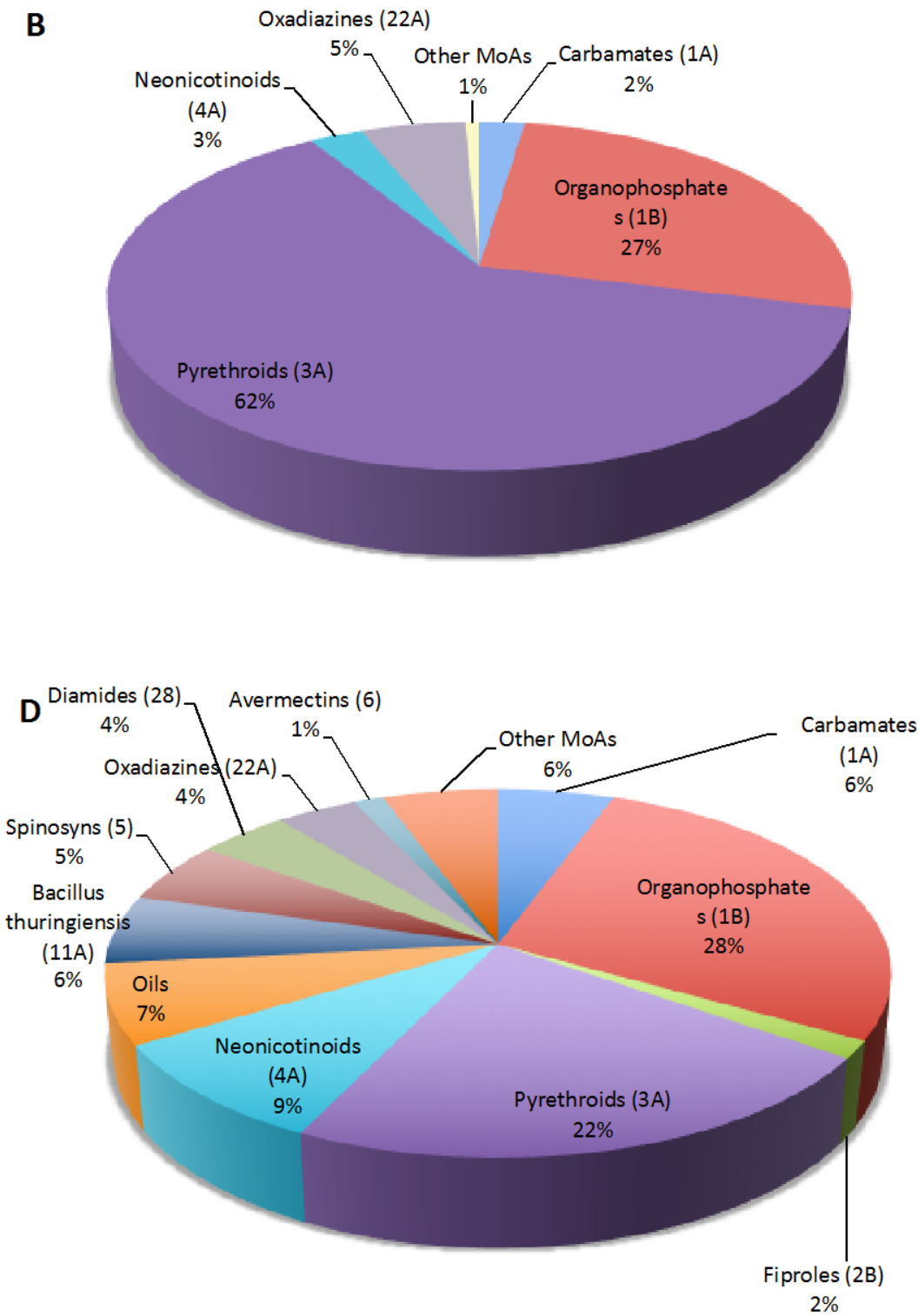

This article is protected by copyright. All rights reserved. 
Figure 1. Estimated insecticide usage in Australia by IRAC MoA group or sub group in (A) cereals, (B) legumes, (C) rape, and (D) all agricultural crops (combined). Data based on the total number of insecticide applications reported by Australian farmers between $2009-2016$ (from market research data collected by Kleffmann Australia and supplied by Bayer CropScience). Data includes 13,244 crop interviews encompassing cereals (wheat, barley, oats, rye, triticale), 2,229 crop interviews encompassing legumes (chick peas, lentils, lupins, field beans, field peas), 2,006 crop interviews involving rape, and 25,450 crop interviews encompassing all agricultural crops (cereals, citrus, cotton, forage crops, fruit, legumes, pastures, potatoes, rape, rice, sugar cane, tropical fruits, vegetables and vines). 
Diamides (28) Oils

Tetronic \& $3 \%$ Tetramic acid Other MoAs

Sulfoximines (4C)$$
6 \%
$$

$$
\%
$$

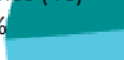

Neonicotinoids

$(4 \mathrm{~A})$
$19 \%$

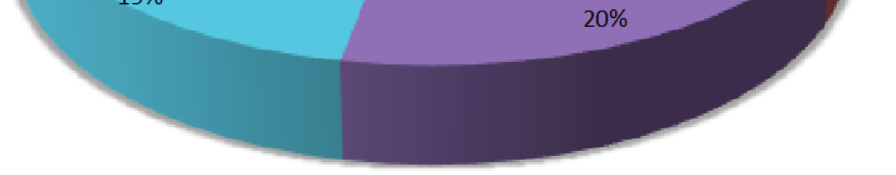

Carbamates (1A)

$18 \%$ Organophosphates

(1B)

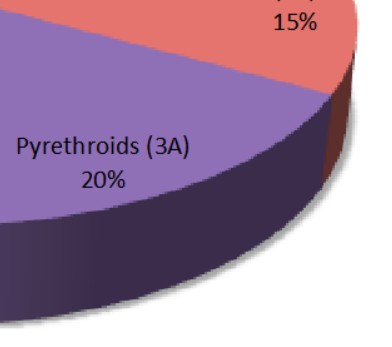

C

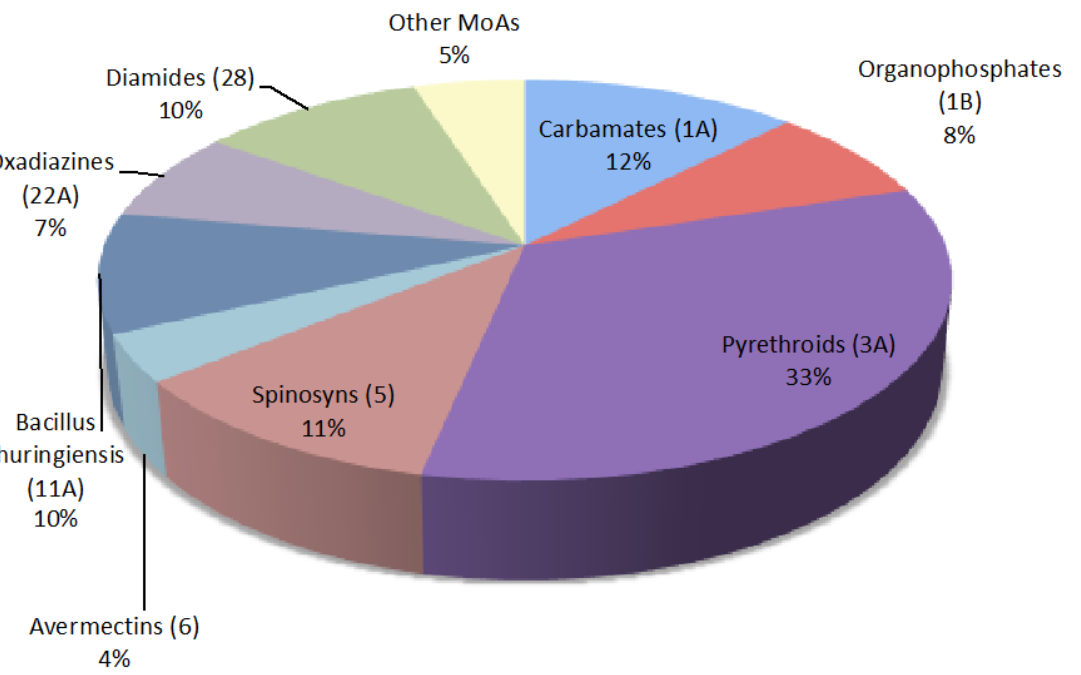

B

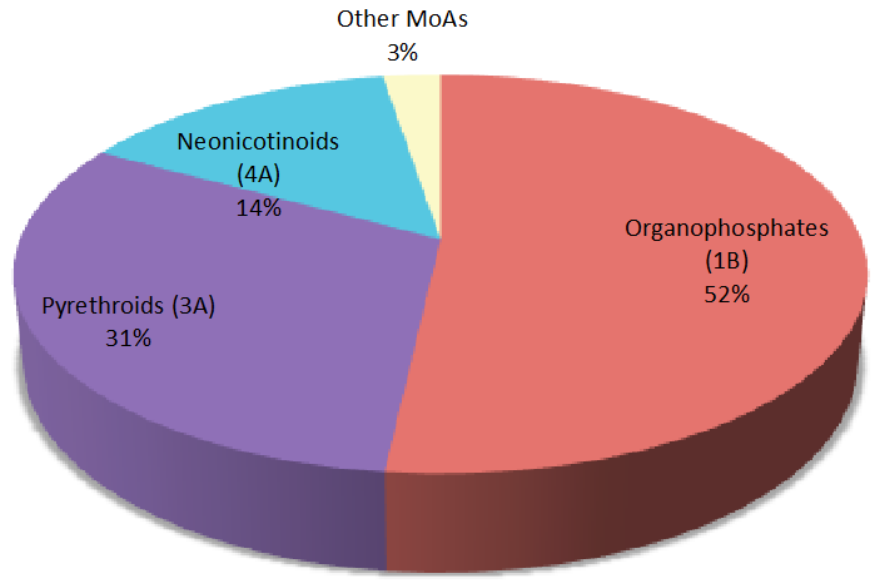

D
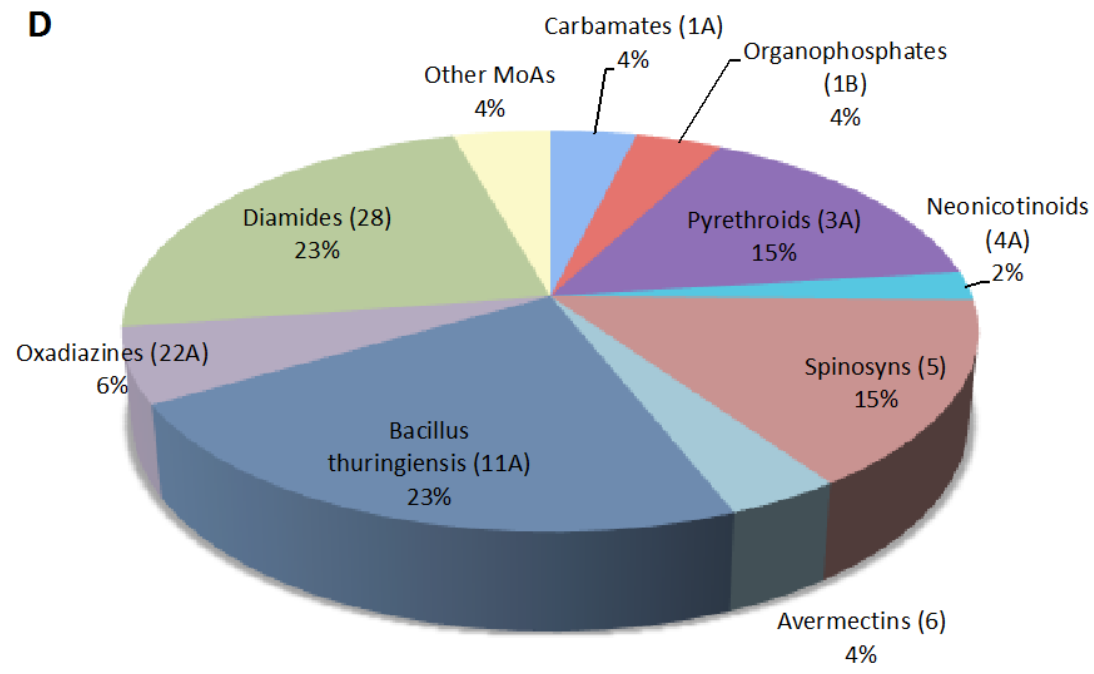

This article is protected by copyright. All rights reserved. 
Figure 2. Estimated insecticide usage in Australia by IRAC MoA groups or sub groups targeting (A) Myzus persicae, (B) Halotydeus destructor, (C) Helicoverpa armigera and (D) Plutella xylostella. Data based on the total number of insecticide applications reported by Australian farmers between 2009-2016 (from market research data collected by Kleffmann Australia and supplied by Bayer CropScience). Data includes 25,450 crop interviews encompassing cereals, citrus, cotton, forage crops, fruit, legumes, pastures, potatoes, rape, rice, sugar cane, tropical fruits, vegetables and vines. 

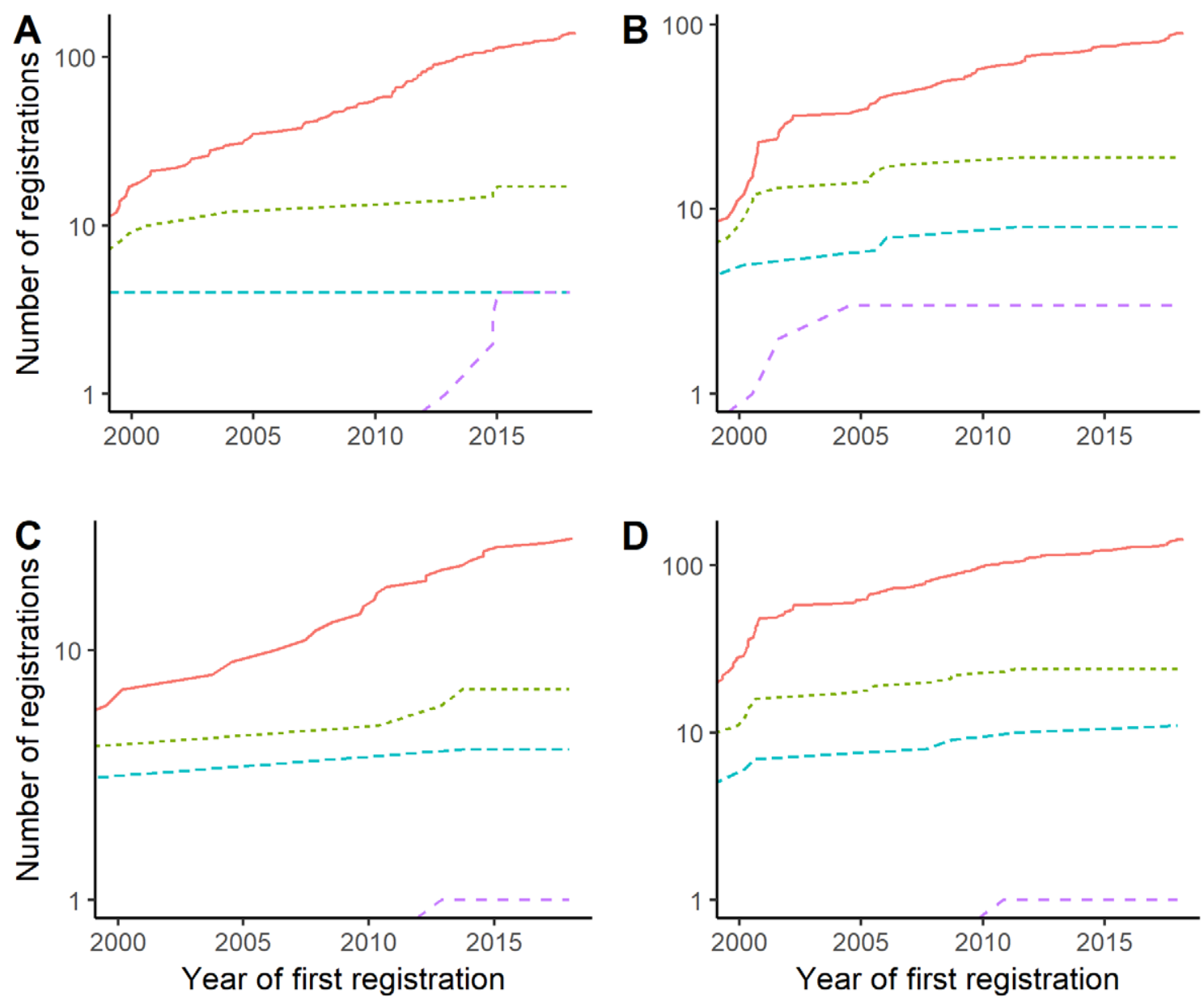

Formulations -...- Active ingredients ---- MoAs - - Mixtures

Figure 3. Trends in chemical registrations in Australian grain crops for key arthropod pests: (A) Halotydeus destructor, (B) Plutella xylostella, (C) Myzus persicae, and (D) Helicoverpa armigera. Data was extracted from the APVMA public registered chemical database. ${ }^{31}$ MoAs refers to active ingredients with unique modes of action. Deregistered formulations are not included. 


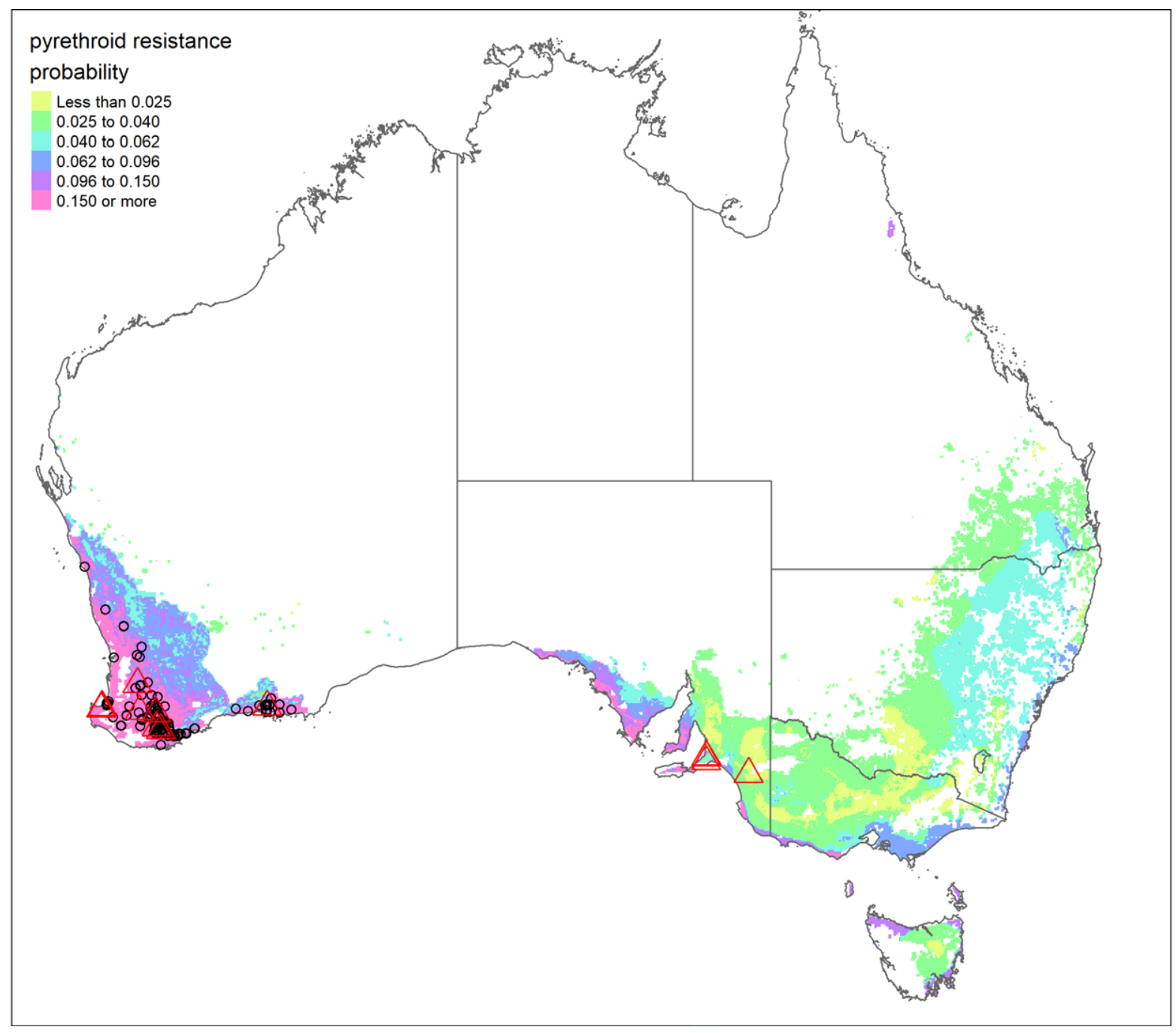

Figure 4. Predicted pyrethroid resistance risk (probability) for Halotydeus destructor. Known resistant populations detected between 2006-2015 used to calibrate the model ${ }^{46}$ (black circles) and newly detected pyrethroid resistance populations identified after 2015 (red triangles). Data for newly detected populations sourced from published findings ${ }^{18}$ and $H$. destructor populations collected and screened for the presence of mutations in the $k d r$ gene known to confer pyrethroid resistance ${ }^{39}$ (Umina $\mathrm{P}$, unpubl data). 


\section{Review:}

Escalating insecticide resistance in Australian grain pests: contributing factors, industry trends and management opportunities

Running title: Insecticide resistance challenges and opportunities in Australian grains

P.A. Umina ${ }^{\mathrm{a}, b^{*}}$, G. McDonald ${ }^{\mathrm{a}}$, J. Maino ${ }^{\mathrm{a}, \mathrm{b}}$, O. Edwards ${ }^{\mathrm{c}}$ and A.A. Hoffmann ${ }^{\mathrm{a}}$

${ }^{\text {a }}$ School of BioSciences, Bio21 Institute, The University of Melbourne, VIC 3068

Australia

${ }^{\mathrm{b}}$ cesar, 293 Royal Parade, Parkville, VIC 3052 Australia

${ }^{\mathrm{c}}$ CSIRO Land \& Water, Underwood Ave, Floreat, WA 6014 Australia

*corresponding author, pumina@unimelb.edu.au

This article is protected by copyright. All rights reserved. 


\begin{abstract}
Insecticide resistance is an ever-increasing problem that threatens food production globally. Within Australia, the grain industry has a renewed focus on resistance due to diminishing chemical options available to farmers and the increasing prevalence and severity of resistance encountered in the field. Chemicals are too often used as the major tool for arthropod pest management, ignoring the potent evolutionary forces from chemical selection pressures that lead to resistance. A complex of factors (biological, social, economic, political, climatic) have contributed to current trends in insecticide usage and resistance in the Australian grain industry. We review the status of insecticide resistance and provide a context for how resistance is currently managed. We discuss emerging technologies and research that could be applied to improve resistance management. This includes generating base-line sensitivity data for insecticides before they are launched, developing genetic diagnostics for the full complement of known resistances, expanding resistance monitoring programs, and utilizing new technologies. Additional benefits are likely to be achieved through a combination of industry awareness and engagement, risk modelling, adoption of IPM tactics, greater collaboration between industry stakeholders, and policy changes around chemical use and record keeping. The Australian grain context provides lessons for other agricultural industries.
\end{abstract}

Keywords: arthropod, insecticide resistance, stewardship, selection pressure, resistance management 


\section{Introduction}

Increased pressure on agricultural production systems to keep up with human population growth has led to innovations to manage pest populations - predominantly with chemical pesticides. For decades, a range of pesticides have reliably and efficiently controlled pest arthropods, weeds and diseases, and new chemistries continue to emerge. However, an over-reliance on chemical controls has escalated the emergence of chemical resistance across a range of pests to a variety of pesticides. ${ }^{1}$ The diminishing number of chemical options that remain effective against some key pests poses serious problems for the continued cost-effective protection of crops. ${ }^{2,3}$ Sustainable management of pesticides is challenging; the relatively short-term goals of local agri-business (sales and profit) and individual farmers (enhanced in-season 'insurance' and/or protection offered by one or multiple applications of relatively low-cost pesticides) often conflict with the community's and industry's broader goals (long-term stewardship of a shared-chemical resource through targeted pesticide applications and fewer chemicals in the environment).

Globally, there are more than 580 documented cases of arthropod pests evolving resistance, and 325 unique chemicals for which one or more species have evolved resistance. ${ }^{1}$ Resistance issues will inevitably continue to increase. This is despite the overall quantity of insecticides being used decreasing in many regions of the world. In the US, the quantity of insecticides applied in many food crops is lower than it was 20-30 years ago. ${ }^{4}$ In part this reduction has been influenced by the introduction of genetically modified crops, ${ }^{4}$ which in turn has increased selection pressure for resistance to those toxins expressed in transgenic plants. The western corn rootworm (Diabrotica virgifera virgifera), for example, has evolved resistance to an insecticidal 
toxin derived from the bacterium Bacillus thuringiensis $(B t)$ after consecutive plantings of the same type of transgenic maize. ${ }^{5}$ In the EU, recent moves towards the sustainable use of pesticides is intended to result in a gradual decrease in insecticide use in several European countries ${ }^{6}$, and in theory minimize the selection of resistance. However, as pointed out in the 'Declaration of Ljubljana', this legislative change could have the adverse effect of increasing the risk of resistance evolution due to a diminished diversity of chemical options for farmers. ${ }^{7}$

Broad approaches to the management of resistance evolution have not fundamentally changed in decades, although new molecular, species-specific and chemical-specific research has been crucial in assisting management in local operational contexts. The speed at which resistance evolves is influenced by many factors including the rate of reproduction, migration and host range of the pest, proximity of susceptible populations, persistence and specificity of the insecticides used, and rate, timing and number of chemical applications. ${ }^{8}$ However, despite this awareness, early warnings and recommendations have been largely ignored, as short-term economic priorities at the individual-level continue to outweigh long-term sustainability and chemical stewardship goals.

Insecticide resistance is increasingly attracting attention within large-scale cropping operations in Australia for a variety of reasons: chemicals continue to be applied prophylactically, ${ }^{9}$ placing high selection pressure for resistance on target pests; some older insecticide groups have been withdrawn by regulatory authorities and others are likely to follow, ${ }^{10}$ which increases reliance on the remaining chemistries; and perhaps most importantly, resistance issues are increasingly emerging, rendering some 
insecticides completely ineffective for particular pests of pastures, grain and horticultural crops. ${ }^{9,11,12}$ Australian farmers are increasingly grappling with resistance problems that threaten effective management of pests traditionally controlled using chemicals.

The Australian grain industry has several features that influence (and complicate) resistance management. Australia's climate contributes to arthropod pest outbreaks being variable, and profit margins being unpredictable and often low. Farms are large and production systems are highly mechanized across large fields. ${ }^{13}$ This situation is similar to the corn belt of the US, but differs from farming in many European and Asian countries where farms and fields tend to be smaller and climate more predictable. Both the marginality and scale of cropping means that regular crop monitoring for arthropods is perceived to be unaffordable, and farmers often resort to low cost 'insurance' sprays to reduce the short-term risk of pest incursions. As Australia is a net exporter of grain, trading standards are high and require very low thresholds of insect contamination or pest damaged grain, often resulting in a stronger emphasis on chemical control. Like a number of other counties (particularly those in the EU), Australia has a partial ban on transgenic crops that prevents farmers from accessing GMO food crops expressing insecticidal traits. If available, these would almost certainly reduce reliance on insecticide applications. ${ }^{14}$

In this paper, we review the status of insecticide resistance in Australian grain crops and provide a context for how resistance is currently managed. We discuss emerging technologies and new research, and then provide an overview of options to 
strategically manage resistance with a view to ensuring the long-term viability of control options available to the industry.

\section{Resistance status in Australian grains and industry trends}

\subsection{Resistance among arthropod grain pests}

A number of important arthropod pests of grain crops have evolved insecticide resistance in Australia. These include Helicoverpa armigera (cotton bollworm), Plutella xylostella (diamondback moth), Myzus persicae (green peach aphid) and Halotydeus destructor (redlegged earth mite). With the exception of H. destructor (a pest largely restricted to Australia and South Africa), these species are known to have resistance both in Australia and overseas (Table 1). Control of H. armigera, $P$. xylostella and M. persicae is complicated by widespread insecticide resistance across multiple chemical groups and different agricultural industries. ${ }^{12,15,16}$ This situation is similar to what is being observed in other countries. For example, M. persicae populations in Europe now possess resistances to a very large number of insecticide groups, which is hampering management efforts by farmers. ${ }^{17}$ For $H$. destructor, resistance is common in Western Australia, and has recently been detected in parts of eastern Australia. ${ }^{11,18}$ Other species considered minor pests of Australian grain crops that have evolved resistance include Bemisia tabaci (silverleaf whitefly), Tetranychus urticae (two spotted mite), Frankliniella occidentalis (western flower thrips) and Thrips tabaci (onion thrips) (Table 1), species that are important global pests.

$<<<$ insert Table $1>>>$

This article is protected by copyright. All rights reserved. 
Given selection pressures are likely to remain high as a result of the ongoing reliance on insecticides in grain and other agricultural industries, it is expected that additional species will evolve resistance in the coming years. Understanding which species are at greater risk of evolving resistance is not straightforward. As a result of changes in farming practices, insecticide usage patterns and climate, the overall pest status of some species is likely to increase. In Australia, these include Sminthurus viridis (lucerne flea), Balaustium medicagoense (Balaustium mite) and Penthaleus spp. (blue oat mite), ${ }^{19}$ species that are major grain pests and frequently targeted with insecticides because they attack crops at the vulnerable seedling stage. ${ }^{20}$ Recent studies have shown difficulties already exist when attempting to control these pests due to inherent tolerance to certain chemicals. ${ }^{21-23}$ Sminthurus viridis for example, is sensitive to organophosphorus chemicals, but tolerant to pyrethroid chemicals. ${ }^{24}$ There are few registered chemical options available to control S. viridis and Australian farmers rely almost exclusively on organophosphates. ${ }^{29}$ This limits the rotational options (see Section 2.2), placing greater selection pressure for resistance on $S$. viridis. While species 'most at risk' of resistance evolution are difficult to confidently predict, useful methods have been developed to assess the likelihood of resistance evolving to fungicides $^{24,25}$ and insecticides ${ }^{26}$ (also see Section 3.2). Similar approaches are starting to be applied to Australian grain pests (Maino, J. unpubl. data) (see also Section 3.2).

\subsection{Insecticide trends in Australian grain systems}

Despite the heavy reliance on chemicals for pest control in Australian grain crops, there is no coordinated database of agrichemical use in Australia (unlike in many other parts of the world). Market research data, typically undertaken by individual 
companies, is often the best means by which to understand crop protection chemical usage patterns. In Australia, there are few unique chemical modes of action (MoA) among the insecticides registered for a given pest and crop combination (Table 1). Moreover, the grains industry is heavily reliant on Group 1 (carbamates $1 \mathrm{~A}$ and organophosphates 1B), Group 3A (pyrethroids) and Group 4A (neonicotinoids) insecticides (Figure 1). This is analogous to the US, where organophosphates, carbamates, neonicotinoids and pyrethroids made up $>75 \%$ of the total insecticide usage (total $\mathrm{kg}$ ) between $2009-2016^{27}$ and is also broadly consistent with global insecticide usage patterns. ${ }^{1}$ In Australia, the older and less expensive chemistries (i.e. organophosphates, pyrethroids) are extensively used in cereal, legume and rape crops. This is particularly the case for cereals (wheat, barley, oats, rye and triticale), with organophosphates and pyrethroids accounting for $>85 \%$ of all estimated insecticide applications (Figure 1A). In legumes, the picture is similar, although pyrethroids are by far the most widely used MoA (Figure 1B). Neonicotinoids are used far less than in cereals. Pyrethroids, organophosphates and neonicotinoids are widely applied in rape crops within Australia. Other MoAs, such as sulfoxomines (Group 4C) and fiproles (Group 2B), are applied less frequently (Figure 1C). When all agricultural crops are considered together, the pattern of insecticide usage differs considerably. While pyrethroids, organophosphates and neonicotinoids remain the most commonly applied chemicals in Australia, there is much greater diversity and spread across MoA groups (Figure 1D). This is not surprising given the higher economic value of most non-grain crops (i.e. vegetables, citrus, potatoes, tropical fruits, rice, sugar cane, cotton and grapes), allowing more expensive insecticidal formulations (e.g. Bt (Group 11A), spinosyns (Group 5), diamides (Group 28) and oils) to be applied in these crops. 
$<<$ insert Figure $1>>>$

A different spectrum of insecticides is used to control various grains pests in Australia, including those for which insecticide resistance is already present. For $M$. persicae, H. armigera and P. xylostella, a large number of MoAs are registered in Australia (Table 1) and a wide variety of MoAs are applied by farmers (Figure 2). This likely reflects the global status of these pests (and thus greater investment from agrichemical companies towards R\&D) and the diversity of agricultural commodities each of these species attack. ${ }^{16,28,29}$ For H. destructor however, the story is very different. Only four unique MoAs are registered against this pest (Table 1). Of these, farmers are heavily reliant on only three: organophosphates, pyrethroids and neonicotinoids (Figure 2B). Given neonicotinoids are only registered as seed dressings against $H$. destructor, this considerably hinders rotational options available for managing resistance.

$<<<$ insert Figure $2>>>$

Globally, there has been a consistent increase in the number of chemical formulations registered in the last two decades, however the number of new active ingredients for many major classes of insecticides has increased at a far slower rate. ${ }^{30}$ This is also true in Australia (see Figure 3). For some grain pests (e.g. H. destructor), new insecticide formulations with unique MoAs have not been registered in more than 15 years. Given that the rotation of chemicals between MoA groups is one of the foundations of resistance mitigation, the limited options of unique chemical groups is 
a key obstacle for farmers. Although new insecticide formulations will no doubt be registered against grain pests in the future, the number of active ingredients with new MoAs entering the market will be limited due to the substantial development costs and increasing regulatory requirements.

$<<<$ insert Figure $3>>>$

Within Australia, insecticides are increasingly applied as mixtures of active ingredients to control grain pests, either through on-farm tank mixes or commercial co-formulated products (Figure 3). This trend is occurring elsewhere in the world, including the US and Europe. Currently, four co-formulations targeting arthropod pests are registered in the Australian grain industry ${ }^{31}$ and more registrations are likely. Insecticide mixtures offer a range of potential benefits. They may provide improved control of pests through synergistic interactions or through potentiation, they may be effective when partial resistance has evolved ${ }^{32}$ and can help target multiple life stages of pests (or a complex of pest species) when these differ in their susceptibility to different chemicals. If the chemicals within a mixture affect different target sites, the likelihood of two (or more) mutations being present simultaneously is extremely low and thus should reduce the rate at which resistance evolves. However, against this, there are various attributes of insecticide mixtures, such as differing decay rates, which may not only reduce the rate at which resistance evolves, but in some situations exacerbate the risk of resistance. ${ }^{33}$ Furthermore, mixtures can have synergistic toxic effects on beneficial arthropods that are greater than the effects of the active ingredients singly, ${ }^{33}$ which can lead to greater chemical use (due to the suppression of 
natural biological control), thus further increase selection pressure for resistance evolution.

In addition to insecticide mixtures, the last decade has seen a substantial increase in the adoption of insecticide seed dressings in Australia, particularly on rape. It is now difficult for farmers to commercially purchase rape seed that is not coated with an insecticide dressing. Seed dressings are also becoming more common on cereals, particularly in response to new threats such as the Russian wheat aphid (Diuraphis noxia), which was first detected in Australia in $2016 .{ }^{34}$ Seed dressings can be effective at curbing pest feeding damage and virus transmission in vulnerable establishing crops. In contrast to foliar sprays, they reduce the risk of chemical exposure to farmers and spray operators, and many beneficial arthropods. They can also reduce carbon emissions through a reduced need to apply foliar chemical sprays to control crop pests. However, the almost universal use of insecticide seed dressings in some crops will hasten the evolution of resistance, such as observed in tobacco thrips (Frankliniella fusca) in cotton fields in the US. ${ }^{35}$ Seed dressings used in Australian grain crops and elsewhere are by their very nature pre-emptive. The decision to use a seed dressing is typically made many months before sowing, well before the opportunity arises to assess the risk of most crop establishment pests. Within Australia, seed dressings mostly contain a neonicotinoid, limiting the opportunity to rotate with seed dressings containing different MoAs. ${ }^{31}$ Resistance of crop pests to neonicotinoids is already commonplace, reaching a level at which some major pests, such as M. persicae and B. tabaci, cannot be effectively controlled.

\subsection{Resistance management in Australian grains}

This article is protected by copyright. All rights reserved. 
Insecticide resistance management strategies (IRMSs) aim to prevent or delay resistance evolving, or to help regain susceptibility in pest populations in which resistance has already arisen. Several IRMSs are currently used in Australia. The most widely adopted by farmers is the Cotton IRMS, which is regionally adapted and includes multiple pests. ${ }^{36}$ More recently, IRMSs have been developed specifically for the grain industry, but these are species-specific, covering $M$. persicae, H. destructor, P. xylostella and H. armigera (https://ipmguidelinesforgrains.com.au). Each of these strategies is underpinned by principles relating to the judicious use of insecticides: (1) only applying chemicals when the pest infestation warrants it; (2) avoiding the application of broad-spectrum formulations as much as practical; and (3) rotation of formulations whereby the same MoA is not applied across consecutive generations of the target pest. As with the Cotton IRMS, the new grain IRMSs also advocate integrated pest management (IPM) tactics, such as minimising the risk of pest buildup on weeds, strategic grazing of crops and pastures by livestock and, in the case of H. armigera, destroying pupae in the stubble of treated fields.

A key challenge facing the Australian grain industry is the adoption of these IRMSs. Similar to overseas experiences, there are considerable barriers preventing the widescale adoption of resistance management in Australia: (1) IRMSs are only available for a few species, and those that exist do not adequately consider the complexities when multiple pests are present; (2) there is tension between local management objectives (e.g. 'insurance' sprays) and those based on regional or industry priorities (e.g. reducing chemical applications to minimize resistance); (3) there have been limited institutional approaches to extend IRMSs to farmers, and (4) scientists often rely on imperfect knowledge when developing IRMSs, and thus the value of long- 
term strategies can be difficult to support with empirical data. And perhaps most importantly, resistance issues in Australia and overseas are often not perceived as a priority for farmers, given the complexity and immediacy of on-farm management decisions they face. As stated by Alyokhin et al. (2008) in relation to resistance management of the classic pest, the Colorado potato beetle (Leptinotarsa decemlineata), "Although there is general acknowledgment of the problem, dealing with it remains low on the average grower's list of priorities". ${ }^{37}$

\section{The future of resistance management in Australian grains}

The Australian Grains Research and Development Corporation (GRDC), together with entomologists and resistance experts, established a National Insecticide Resistance Management (NIRM) working group in 2013. NIRM has been responsible for: (1) developing IRMSs for key pests, focusing on species where resistance is present; (2) facilitating interactions with CropLife Australia and stakeholder feedback between agrichemical companies, scientists and farmers; and (3) providing connections with other agricultural industries facing insecticide resistance issues in Australia. The establishment of NIRM has been a valuable step forward and is a model worth instituting in other agricultural industries grappling with similar resistance issues. However, obstacles still exist, that prevent effective management of resistance. In Table 2 and below we outline some key elements necessary to overcome these obstacles in order to strategically manage resistance in Australian grain pests and help preserve the efficacy of important chemicals.

$<<<$ insert Table $2>>>$ 


\section{$\underline{3.1 \text { Baseline data and resistance monitoring programs }}$}

Before the introduction of any new MoA, it would be wise to define dose-response relationships for target pests, especially for species such as $M$. persicae and $P$. xylostella that have a high propensity to evolve insecticide resistance. New testing methodologies may need development as new formulations with unique chemistries are identified. Baseline sensitivity data should be generated for a representative collection of field populations that encompass the geographical spread of a pest and relevant cropping systems. The vast majority of new insecticide formulations currently entering the Australian market are introduced without the data needed to implement sound IRMSs (Table 2).

Once insecticide baseline data are established, regular monitoring of field performance should be carried out, so the incidence, distribution and nature of resistance can be established and reduced through active management. Resistance monitoring efforts should not only target grain crops, but encompass other agricultural industries where the species in question are known to be pests. This is particularly important for pests where the intensity of selection pressure from insecticides is equivalent or greater in crops outside of the grain industry. Most horticultural crops in Australia, for example, receive on average, more insecticides per growing season than grain crops, and a handful of studies have revealed high gene flow in pests across horticultural and grain industries (e.g. de Little ${ }^{38}$ ). Where available, scientists should make use of genetic markers to aid monitoring programs. New genomic tools can greatly assist in monitoring programs aimed at understanding ongoing processes as new resistance alleles with different costs and inheritance patterns are discovered in treated populations. DNA-based tests have recently been 
implemented for resistance screening of $H$. destructor and $M$. persicae populations in Australia, ${ }^{12,39}$ and are used to screen for certain resistances in H. armigera. ${ }^{40}$ Surprisingly, similar tools have not been widely developed and utilized for routine resistance surveillance in $P$. xylostella and other important species in Australia, even though many resistance mechanisms have been identified. ${ }^{41}$ New molecular approaches (e.g. CRISPR) offer novel opportunities to identify resistance mechanisms that have previously proven difficult. ${ }^{42}$

National programs for insecticide resistance monitoring for major grain pests should be implemented as a matter of priority. Importantly, these programs should evaluate the proportion of susceptible individuals over time. These comparisons will help detect resistance alleles while at a low frequency in populations, when resistance management programs have a much greater chance of success. The value of such proactive programs is evidenced by the detection of Vip3A resistance alleles in $H$. armigera populations before the commercial release of transgenic cotton expressing the toxin. ${ }^{43}$

Because some arthropods are highly mobile, gene flow often occurs between populations in different countries, which can influence resistance patterns. Certain $M$. persicae resistance alleles have migrated to the UK from continental Europe. ${ }^{44}$ An 'Asian pyrethroid resistance allele' was recently detected in Australian populations of H. armigera (Edwards O, unpubl. data), while a recent incursion of $H$. armigera into Brazil included individuals with resistance to pyrethroids. ${ }^{45}$ The risk of incursions into Australia is likely to be lower than many other countries due to the strong quarantine and biosecurity system in place and Australia's island status. However, 
Australia's border is enormous, and there is a rapidly increasing movement of goods and people across it. The incursion of two very damaging pests, D. noxia and Bactericera cockerelli (tomato potato psyllid), in the last 2 years highlight the enormity of the challenge. For pests already established in a country, new resistances could be introduced through gaps in the quarantine system. A recent genetic study involving more than 170 Australian populations and 40 overseas populations of $M$. persicae (using 50 polymorphic microsatellite DNA markers) indicates resistant biotypes may have arrived in Australia from overseas, and quickly spread across the country (Weeks A, 2017, pers. comm.). Consequently, we suggest resistance monitoring of cosmopolitan pests should include international biotypes for benchmarking of global conspecifics.

\subsection{Modelling and risk analysis}

An understanding of resistance risks can be enhanced through statistical models (identifying patterns in complex data sets) and computer simulation studies (simulating resistance outcomes under different selection or evolutionary scenarios). Both help to bring additional value to the monitoring and management programs described earlier (Table 2). For example, models can aid in identifying high-risk areas or practices for pre-emptive management. ${ }^{46}$ The evolution and management of insecticide resistance is multi-dimensional, and computational approaches help in making this complexity more manageable, and in identifying factors influencing resistance risk. $^{47}$

Large data sets on different chemical practices, land usage or climatic patterns can be incorporated into predictive models that test for statistical correlations between 
resistance and model inputs. An advantage of large-scale copping systems such as the Australian and US grain landscapes is that relatively coarse environmental data can be leveraged to gain insights into resistance risks (e.g. 5-km resolution data would be less relevant for horticulture). A technique commonly applied in machine learning was recently used to successfully capture the current distribution of insecticide resistance of $H$. destructor within Australia from environmental and management factors hypothesized to increase resistance risk. This modelling highlighted geographic locations without resistance, but with similar properties to areas with resistance. ${ }^{46}$ Since this study, resistant field populations have been detected within regions identified as high-risk (Figure 4), thus demonstrating the value of such approaches. Using a compiled data set on the biological traits of 902 arthropod species, Hardy ${ }^{26}$ identified strong associations between diet breath and voltinism, and the propensity of a pest to evolve resistance (as well as the number of MoA groups to which resistance has evolved). Such approaches not only help to explain how resistance might evolve, but can promote resistance management of high risk species before it evolves.

$<<<$ insert Figure $4>>>$

While statistical approaches can be useful for interpreting large and multidimensional data sets, a shortcoming of correlative approaches is that identified patterns may be spurious and form an unreliable basis for prediction, particularly when extrapolating to novel conditions. ${ }^{48}$ To address this issue, other modelling approaches (e.g. simulation studies) restrict predictions to 'realistic' values by incorporating detailed knowledge on how resistance evolves. Knowledge that can be 
incorporated includes the genetic basis of resistance, selection pressures acting on resistance alleles, costs associated with resistance, the mode of reproduction of species, or patterns of gene flow in pests that can dilute the effects of resistance or cause it to spread locally or from other industries. ${ }^{49-51}$ These models require a detailed understanding of the biology and ecology of the pest organism as well as the genetic basis of resistance within the local context and the origin of resistance. Unfortunately, genetic data is mostly unavailable for Australian grain pests and indeed most agricultural pests globally. Helicoverpa armigera is one of a few exceptions, where information has been available on costs and the genetic basis of resistance based on research efforts spanning multiple decades. ${ }^{15}$

\section{$\underline{3.3 \text { Greater adoption of IPM }}$}

In the Australian context, both crop scale and uncertain profitability contribute to the poor adoption of IPM, and a heavy reliance on broad-spectrum pesticides to 'insure' against or combat pest occurrences, particularly during crop establishment. ${ }^{13,20}$ However, the widescale adoption of IPM would go a long way towards minimizing and managing insecticide resistance. IPM employs a package of tactics to reduce pest pressures, and in grain crops can include cultural and agronomic practices that suppress pests (e.g. pre-crop grazing, multi layered shelterbelts, early sowing), the removal of alternate plant hosts and the use of pest monitoring practices and economic thresholds to guide chemical decision-making (Table 2). Combined, these approaches reduce farmers' reliance on insecticides for pest management. The impact of non-selective insecticide applications on beneficial arthropods and their compatibility with IPM also need to be considered. Predators and parasitoids can play an important role in resistance management, especially when part of an established 
IPM program, as exemplified by P. xylostella management in Australian rape crops. ${ }^{16}$ If farmers were able to rely more on beneficial arthropods, fewer insecticide applications would be needed, reducing selection pressures. The success of the Australian cotton IRMS has in part been realized through increased reliance by farmers on biological control. ${ }^{36}$ Beneficial arthropods are encouraged through decreasing the frequency of insecticide applications and increasing their selectivity, as well as providing refuge habitat (e.g. remnant vegetation, windbreaks) and alternate food sources (e.g. nectar sources, non-pest hosts). ${ }^{52}$ There are critical knowledge gaps in Australian grain systems for implementing such an approach (Table 2). Of course, these obstacles are almost ubiquitous across all developed countries. In the developing world, successful adoption of IPM is further impeded by resource-poor farmers which are typically supported by insufficient training, and weak extension agencies and networks. ${ }^{53}$

The use of broad-spectrum insecticides disrupts biological control through direct toxicity to beneficial species, and indirectly by changing arthropod communities. While insecticide seed dressings are now widely used in grains, and have less pervasive effects on beneficial organisms than conventional high-volume sprays, they can still adversely impact arthropod predator and parasitoid communities. ${ }^{54,55}$ This is an important issue given the scale at which these insecticides are now being applied. Outside of beneficial arthropods, a lack of economic thresholds for key pests is a major constraint to the adoption of IPM in Australian grain crops and elsewhere. In part, this leads to indecision and the prophylactic application of insecticides potentially increasing the risk of resistance. The risk is dependent on numerous factors such as the genetic basis of resistance across field doses, the starting resistance 
allele frequencies and pest dispersal rates. ${ }^{56}$ Thresholds help to rationalize the use of insecticides and are a fundamental tenet underpinning IPM practices, ${ }^{57}$ assuming they are accurate and appropriately applied. A recent review commissioned by the GRDC identified numerous gaps in economic thresholds available within the Australian grain industry (Miles M, 2018, pers. comm.). For most pests, there are either no economic thresholds or those that do exist are only regionally relevant and/or nominal (i.e. subjective, without an empirical basis). Thresholds are deemed appropriate for at least 35 major pest group/crop combinations in grains, but a dynamic threshold is available for only one species (H. armigera), with none that account for the impact of beneficial organisms suppressing the pest (Miles M, 2018, pers. comm.). This paucity of dynamic thresholds, which can take years of research to develop for a single pest, is common for most crops around the world. ${ }^{58}$

\subsection{Embracing emerging technologies}

Molecular technologies present novel solutions to previously intractable problems in resistance management and some of these have application to Australian grain pests. For example, CRISPR technology could be deployed to modify the genome of pests and, using a natural or synthetic gene drive mechanism ${ }^{59}$, drive susceptible alleles back into resistant populations. Helicoverpa armigera would be a strong candidate because many simple resistance mutations to $B t$ toxins have already been identified, ${ }^{60}$ and this approach could be integrated into an existing resistance management program. ${ }^{40}$ Also, CRISPR-based editing of a $B t$ resistance allele has already been achieved in this species ${ }^{61}$ and more recently, used to reverse engineer susceptibility to two different insecticide groups by targeting cytochrome P450 monooxygenases. ${ }^{42}$ Another potential application is to edit insecticide target site genes into important 
beneficial arthropods to make them tolerant to insecticides (and hence not be disrupted by applications against target pests), however, potential unintended ecological consequences (e.g. intraguild predation) would need to be carefully considered before such an approach was attempted. Insecticide-resistant natural enemies generated through laboratory selection have been used safely and successfully as part of IPM programs in the past. ${ }^{62}$

A more contained method to drive down resistance alleles is the sterile insect technique, SIT. ${ }^{59}$ Recent modelling indicates the mass release of a male selecting strain of P. xylostella carrying insecticide susceptible alleles can effectively drive susceptibility into target populations. ${ }^{63}$ The challenge of this approach is the cost of producing sufficient numbers of released males to affect target populations, particularly in large broad-acre fields. Recent developments in robotics and automation could help to address this issue, but the costs of diet reagents might still be prohibitive. Using new sensors and big data analysis to quantify pests and/or injury to plants could help to alleviate the time constraints of crop monitoring necessary in IPM. ${ }^{58}$ Transgenic crops represent another opportunity to improve the way a number of grain pests are managed. The introduction of transgenic crops expressing insecticidal properties has transformed global agriculture, with their adoption continuing to grow annually. Like many other countries however, Australia has only seen the commercialisation of insect tolerant cotton; ${ }^{36}$ and there are currently no insecticidal transgenic food crops grown commercially. The potential benefits to resistance management, as observed in other systems, ${ }^{64}$ could be realized if host plant resistance is introduced to crops, such as oilseeds, pulses, cereals and sorghum. Helicoverpa armigera and $P$. xylostella would be obvious targets in grain crops 
expressing $B t$ toxins, while virus resistant traits, similar to those deployed in other systems, ${ }^{65}$ would result in significant reductions in insecticide sprays against species like $M$. persicae.

\subsection{Policy and market drivers for change}

The need for wider IPM implementation in Australia has not yet made the political agenda. Recent experience in the EU provides an example of a policy intervention driven by a commitment to public health concerns and market access issues that has changed the way pesticides are licensed, produced and used, ${ }^{6}$ and emphasized IPM principles. ${ }^{66}$ However, it may have had some unexpected consequences. Selection for insecticide resistance might be expected to decline as IPM is progressively implemented, although in the EU (under related legislation ${ }^{67}$ ), fewer MoAs now available may counter any gains towards minimizing selection pressure. Additionally, the recent ban on neonicotinoids has likely increased use of older insecticides. ${ }^{68}$ In Australia, any government policy that enhances IPM implementation will only occur as part of a broader policy thrust. ${ }^{69}$ The most likely regulatory intervention pathway is through the Australian Pesticides and Veterinary Medicines Authority (APVMA), which may gradually withdraw some older insecticide chemistries in line with the EU and other OECD countries. However, unlike in the EU, a key driver is likely to be demands of export markets for low arthropod and chemical residues in grain. While this could encourage IPM adoption through the withdrawal of some broad-spectrum insecticides and indirectly making biological insecticide sprays (e.g. Bt and NPV) more cost competitive, it may also limit MoA rotation options for managing resistance to newer chemistries. In the US, there is a long-established program (the IR-4 Project) that facilitates the registration of formulations in minor crops to 
overcome a longstanding problem of limited chemical options in those commodities with a market share that is too small to justify the expense of chemical registration. ${ }^{70}$ A similar initiative has been launched in Australia (http://www.agriculture.gov.au/agfarm-food/ag-vet-chemicals/improved-access-agvet-chemicals) and could lead to more diverse MoAs being applied to facilitate resistance management programs; however, if not managed carefully, new registrations could increase the use of already popular (and commonly-used) chemicals. We advocate an extension of these programs that involves incentives to agrichemical companies for implementing stewardship practices around insecticide resistance, as was recently proposed for herbicides. $^{71}$

\section{$\underline{3.6 \text { Cross industry considerations }}$}

Insecticide resistance in Australia appears more likely in polyphagous arthropods ${ }^{72}$ that are pests across multiple agricultural industries (grains, cotton, horticulture and pastures) (see Table 1) and move freely between them. Resistance management strategies need to account for differing selection pressures across industries both in terms of the intensity of selection and timing. Because of commercial sensitivity, agrichemical companies do not provide the relative quantities of chemicals being applied to pests across crops, making it hard to model relative selection pressures. This is further complicated by the fact that insecticide formulations registered for particular pests can vary between industries. Current resistance management strategies are industry-focussed, but overall selection pressure for resistance to any MoA is unlikely to decline if the same chemical continues to be used in an unrestricted way in another industry. 
Although this threat is widely appreciated across Australia's agricultural industries, there are no formal or integrated processes for collaboration. Greater cross-industry collaboration for successful stewardship of resistance management in Australia is needed and should involve stakeholders such as farmers (following labels, rotating chemicals), CropLife Australia and agrichemical companies (advocacy, stewardship of chemicals), funding organizations and research scientists (resistance monitoring, developing IPM strategies), and government extension staff and farm advisors (advocacy, providing advice) (Table 2).

\section{$\underline{3.7 \text { Communication and extension }}$}

The success of any IRMS is contingent on consistently applying the principles of the strategy, and yet the uptake of these principles remains relatively low among Australian grain farmers. ${ }^{73}$ To achieve greater IRMS uptake, a structured communication and extension effort is needed. This challenge is not easily resolved. Numerous barriers (and drivers) influence the uptake of resistance management guidelines, such as knowledge (e.g. economic thresholds), economic (e.g. cheap alternatives) and social (e.g. prior perceptions, uncertainty, peer pressure, decision making complexity) factors. ${ }^{73}$ While knowledge and economic factors are undoubtedly important and well publicized, social factors play a profound and often discrete role in farmer decisions regarding pest management decisions. ${ }^{74}$ This social dimension is not well understood in the Australian grain industry and is also an issue

elsewhere. ${ }^{75}$ A long-term, structured and tailored plan is required to facilitate and evaluate practice change. For example, resistance guidelines might be better packaged as part of an overall IPM program rather than communicating IRMSs as discrete plans, leaving the integration into existing management approaches up to the 
individual farmer (or farm advisor). Lessons can be gleaned from the Australian cotton industry, which has an IMRS that is communicated through a fully integrated and enduring 'one-stop-shop' web and training resource, coordinated by a consortium of research scientists, extension specialists, agronomists and agrichemical company representatives. $^{36}$

Effective management of resistance will also require a coordinated effort to monitor changes in chemical use patterns driven by the IRMSs. Changes can only be monitored if chemical usage information is readily available, but this represents a current gap. The EU and OECD provide methodologies for collecting pesticide usage statistics, ${ }^{76}$ but these are expensive and onerous. Company-based databases capture large-scale chemical use information, mostly through farm management software, but the generated data are not widely accessible, analyzed seasonally or linked to practice change. A national database of agrichemical usage that provides information across regions and sorted by crop and target pest is required. This information would indicate selection pressures for target pests and whether there is practical change in response to IRMSs. Such a database would also considerably improve the ability to assess future resistance threats.

\section{Conclusions}

Insecticide resistance challenges are increasing globally. Within the Australian grains industry, this is highlighted by the recent emergence of resistance in $H$. destructor, $M$. persicae and P. xylostella as well as ongoing problems with resistance in $B$. tabaci and $H$. armigera. At present, resistance issues are dealt with in a mostly reactive manner once resistance has arisen rather than proactively. This makes the industry 
dependent on new chemistries or transformational technologies. With a proactive approach, the risk of resistance evolving in the first place can be minimized by reducing selection pressures while suppressing pest populations. Multiple tactics for managing pests through IPM programs will reduce exposure to insecticides. A proactive, integrated approach should include:

(1) Identifying risk. Progress is needed in identifying pests likely to evolve resistance in the future, as well as understanding regional factors that reduce selection pressures. (2) Resistance management. Once resistance evolves, strategies need to be widely and consistently adopted to ensure resistances remain localized. An industry-wide and cross industry initiative can minimise spread across regions and between industries. (3) Socio-political initiatives. Policy reforms and/or incentive programs that enforce and promote management changes across agricultural industries will significantly reduce selection pressures.

These are important components in all resistance management programs that target not only insecticides but also herbicides and fungicides. ${ }^{75}$

\section{Acknowledgements}

Thanks to members of NIRM, GPAC and others who have contributed ideas and discussion papers that form part of this manuscript, and the GRDC who have supported much of our resistance research. We would like to acknowledge Melina Miles and Nancy Schellhorn for comments and earlier contributions, as well as several anonymous reviewers and the editorial team. Thanks to Bayer CropScience for kindly sharing Australian insecticide market research data and assistance with interpretation. Thanks also to Elia Pirtle and Frances Morell for technical assistance. 


\section{References}

1 Sparks TC and Nauen R, IRAC: Mode of action classification and insecticide resistance management, Pestic Biochem Physiol 121: 122-128 (2015).

2 Whalon ME, Mota-Sanchez D, and Hollingworth RM, Analysis of global pesticide resistance in arthropds, In Global pesticide resistance in arthropods, ed. by Whalon ME, Mota-Sanchez D, and Hollingworth RM, Cornwell Press, Trowbridge pp. 5-31 (2008).

3 Cloyd RA, Western flower thrips (Thysanoptera: Thripidae) and insecticide resistance: An overview and strategies to mitigate insecticide resistance development, J Entomol Sci 51: 257-273 (2016).

4 Osteen CD and Fernandez-Cornejo J, Economic and policy issues of U.S. agricultural pesticide use trends, Pest Manag Sci 69: 1001-1025 (2013).

5 Gassmann AJ, Petzold-Maxwell JL, Keweshan RS, and Dunbar MW, Fieldevolved resistance to Bt maize by Western corn rootworm, PLoS One 6 (2011).

6 European Union, Directive 2009/128/EC of the European parliament and of the council of 21 October 2009 establishing a framework for community action to achieve the sustainable use of pesticides, Off J Eur Union 52: 71-86 (2009).

7 Bielza P, Denholm I, Loannidis P, Sterk G, Leadbeater A, Leonard P, et al., The impact of a declining European pesticide portfolio on resistance management, Outlooks Pest Manag 19: 246-248 (2008).

8 Roush RT and Tabashnik BE, Pesticide resistance in arthropods, Springer Science \& Business Media, Berlin (1990).

9 Downes S and Mahon R, Evolution, ecology and management of resistance in Helicoverpa spp. to Bt cotton in Australia, J Invertebr Pathol 110: 281-286 (2012).

10 APVMA, Omethoate: Regulatory Decisions, 2016. https://apvma.gov.au/node/20151 [accessed 12 April 2018].

11 Umina PA, Weeks AR, Roberts J, Jenkins S, Mangano GP, Lord A, et al., The current status of pesticide resistance in Australian populations of the redlegged earth mite (Halotydeus destructor), Pest Manag Sci 68: 889-896 (2012).

12 Umina P, Edwards O, Carson P, Van Rooyen A, and Anderson A, High levels of resistance to carbamate and pyrethroid chemicals widespread in Australian Myzus persicae (Hemiptera: Aphididae) populations, J Econ Entomol 107: 1626-1638 (2014). 
13 Nash MA and Hoffmann AA, Effective invertebrate pest management in dryland cropping in southern Australia: the challenge of marginality, Crop Prot 42: 289-304 (2012).

14 Phipps RH and Park JR, Environmental benefits of genetically modified crops: Global and European perspectives on their ability to reduce pesticide use, $J$ Anim Feed Sci 11: 1-18 (2002).

15 Forrester NW, Cahill M, Bird LJ, and Layland JK, Management of pyrethroid and endosulfan resistance in Helicoverpa armigera (Lepidoptera, Noctuidae) in Australia, Bull Entomol Res: R1-132 (1993).

16 Furlong MJ, Spafford H, Ridland PM, Endersby NM, Edwards OR, Baker GJ, et al., Ecology of diamondback moth in Australian canola: Landscape perspectives and the implications for management, Aust J Exp Agric 48: 14941505 (2008).

17 Bass C, Puinean AM, Zimmer CT, Denholm I, Field LM, Foster SP, et al., The evolution of insecticide resistance in the peach potato aphid, Myzus persicae, Insect Biochem Mol Biol 51: 41-51 (2014).

18 Maino JL, Binns M, and Umina P, No longer a west-side story - Pesticide resistance discovered in the eastern range of a major Australian crop pest, Halotydeus destructor (Acari: Penthaleidae), Crop Pasture Sci 69: 216-221 (2018).

19 Hoffmann AA, Weeks AR, Nash MA, Mangano GP, and Umina PA, The changing status of invertebrate pests and the future of pest management in the Australian grains industry, Aust J Exp Agric 48: 1481-1493 (2008).

20 Micic S, Hoffmann AA, Strickland G, Weeks AR, Bellati J, Henry K, et al., Pests of germinating grain crops in southern Australia: An overview of their biology and management options, Aust J Exp Agric 48: 1560-1573 (2008).

21 Umina PA and Hoffmann AA, Tolerance of cryptic species of blue oat mites (Penthaleus spp.) and the redlegged earth mite (Halotydeus destructor) to pesticides, Aust J Exp Agric 39: 621-628 (1999).

22 Roberts JMK, Umina PA, Hoffmann AA, and Weeks AR, The tolerance of the lucerne flea, Sminthurus viridis (Collembola: Sminthuridae), to currently registered pesticides in Australia, Aust J Entomol 48: 241-246 (2009).

23 Arthur AL, Hoffmann AA, Umina PA, and Weeks AR, Emerging pest mites of grains (Balaustium medicagoense and Bryobia sp.) show high levels of 
tolerance to currently registered pesticides, Aust J Exp Agric 48: 1126 (2008).

24 Kuck K and Russell P, FRAC: Combined resistance risk assessment, In Fungicide Resistance: are we winning the battle but losing the war?, ed by Bryson RJ, Burnett FJ, Foster V, Fraaije BA and Kennedy R, AAB Conference Proceedings, Aspects of Applied Biology 78, 3-10 (2006).

25 Grimmer MK, van den Bosch F k., Powers SJ, and Paveley ND, Fungicide resistance risk assessment based on traits associated with the rate of pathogen evolution, Pest Manag Sci 71: 207-215 (2015).

26 Hardy NB, Peterson DA, Ross L, and Rosenheim JA, Does a plant-eating insect's diet govern the evolution of insecticide resistance? Comparative tests of the pre-adaptation hypothesis, Evol Appl 11: 739-747 (2018).

27 U.S. Department of the Interior, Pesticide National Synthesis Project, 2018. https://water.usgs.gov/nawqa/pnsp/usage/maps/county-level/ [accessed 22 November 2018].

28 Umina P, Edwards O, Baker G, Downard P, Hoffmann A, McDonald G, et al., The science behind the Resistance Management Strategy for the green peach aphid (Myzus persicae) in Australian grains, Grains Research and Development Corporation, Canberra, Australia, p. 12 (2014).

29 Bird L, Miles M, Cornwell G, Umina P, McDonald G, Hoffmann A, et al., The science behind the Resistance Management Strategy for the Helicoverpa armigera in Australian grains, Grains Research and Development Corporation, Canberra, Australia, p. 26 (2018).

30 Sparks TC and Lorsbach BA, Agrochemical discovery - building the next generation of insect control agents, In Advances in agrochemicals: Ion channels and G Protein-Coupled Receptors (GPCRs) as targets for pest control, ed. by Gross AD, Ozoe YO, and Coats JR, Oxford University Press, pp. 1-17 (2017).

31 APVMA, Public Chemical Registration Information System Search, 2018. https://portal.apvma.gov.au/pubcris [accessed 12 April 2018].

32 Ahmad M, Potentiation between pyrethroid and organophosphate insecticides in resistant field populations of cotton bollworm Helicoverpa armigera (Lepidoptera: Noctuidae) in Pakistan, Pestic Biochem Physiol 91: 24-31 (2008).

33 Cloyd RA, Pesticide mixtures, In Pesticide mixtures, pesticides-formulations, 
effects, fate, ed. by Stoytcheva A, Intech, Croatia, pp. 69-80 (2011).

34 Yazdani M, Baker G, DeGraaf H, Henry K, Hill K, Kimber B, et al., First detection of Russian wheat aphid Diuraphis noxia Kurdjumov (Hemiptera: Aphididae) in Australia: a major threat to cereal production, Austral Entomol doi: 10.1111/aen.12292 (2018).

35 Huseth AS, Chappell TM, Langdon K, Morsello SC, Martin S, Greene JK, et al., Frankliniella fusca resistance to neonicotinoid insecticides: an emerging challenge for cotton pest management in the eastern United States, Pest Manag Sci 72: 1934-1945 (2016).

36 Wilson LJ, Whitehouse MEA, and Herron GA, The management of insect pests in Australian cotton: an evolving story, Ann Rev Entomol 63: 215-237 (2018).

37 Alyokhin A, Baker M, Mota-sanchez D, Dively G, and Grafius E, Colorado potato beetle resistance to insecticides, Am J Potato Res 6: 395-413 (2008).

38 de Little SC, Edwards O, van Rooyen AR, Weeks A, and Umina PA, Discovery of metabolic resistance to neonicotinoids in green peach aphids (Myzus persicae) in Australia, Pest Manag Sci 73: 1611-1617 (2017).

39 Edwards O, Walsh T, Metcalfe S, Tay T, Hoffmann A, Mangano P, et al., A genomic approach to understanding pyrethroid resistance in the redlegged earth mite, Halotydeus destructor, Pestic Biochem Physiol 144: 83-90 (2018).

40 Downes S, Mahon RJ, Rossiter L, Kauter G, Leven T, Fitt G, et al., Adaptive management of pest resistance by Helicoverpa species (Noctuidae) in Australia to the Cry $2 \mathrm{Ab} \mathrm{Bt}$ toxin in Bollgard II ${ }^{\circledR}$ cotton, Evol Appl 3:574-584 (2010).

41 Furlong MJ, Wright DJ, and Dosdall LM, Diamondback moth ecology and management: problems, progress, and prospects, Annu Rev Entomol 58: $517-$ 541 (2013).

42 Wang H, Shi Y, Wang L, Liu S, Wu S, Yang Y, et al., CYP6AE gene cluster knockout in Helicoverpa armigera reveals role in detoxification of phytochemicals and insecticides, Nat Commun 9: 4820 (2018).

43 Mahon RJ, Downes SJ, and James B, Vip3A resistance alleles exist at high levels in Australian targets before release of cotton expressing this toxin, PLoS One 7:e39192 (2012).

44 Fenton B, Malloch G, Woodford JT, Foster SP, Anstead J, Denholm I, et al., The attack of the clones: tracking the movement of insecticide-resistant peach- 
potato aphids Myzus persicae (Hemiptera: Aphididae), Bull Entomol Res 95: 483-494 (2005).

45 Tay WT, Walsh TK, Downes S, Anderson C, Jermiin LS, Wong TKF, et al., Mitochondrial DNA and trade data support multiple origins of Helicoverpa armigera (Lepidoptera, Noctuidae) in Brazil, Sci Reports 7: 45302 (2017).

46 Maino JL, Umina PA, and Hoffmann AA, Climate contributes to the evolution of pesticide resistance, Glob Ecol Biogeogr 27: 223-232 (2018).

47 Hackett SC and Bonsall MB, Type of fitness cost influences the rate of evolution of resistance to transgenic Bt crops, J Appl Ecol 53: 1391-1401 (2016).

48 Maino JL, Kong JD, Hoffmann AA, Barton MG, and Kearney MR, Mechanistic models for predicting insect responses to climate change, Curr Opin Insect Sci 17: 81-86 (2016).

49 Renton M, Shifting focus from the population to the individual as a way forward in understanding, predicting and managing the complexities of evolution of resistance to pesticides, Pest Manag Sci 69: 171-175 (2012).

50 Bourguet D, Delmotte F, Franck P, Guillemaud T, Reboud X, Vacher C, et al., The skill and style to model the evolution of resistance to pesticides and drugs, Evol Appl 3: 375-390 (2010).

51 Tabashnik BE, Computer Simulation as a Tool for Pesticide Resistance Management, In Pesticide Resistance: Strategies and Tactics for Management, ed. by National Research Council, National Academies Press, Washington, pp. 194-206 (1986).

52 Landis DA, Menalled FD, Costamagna AC, and Wilkinson TK, Manipulating plant resources to enhance beneficial arthropods in agricultural landscapes, Weed Sci 53: 902-908 (2005).

53 Parsa S, Morse S, Bonifacio A, Chancellor TCB, Condori B, Crespo-Pérez V, et al., Obstacles to integrated pest management adoption in developing countries, Proc Natl Acad Sci USA 111: 3889-3894 (2014).

54 Douglas MR and Tooker JF, Meta-analysis reveals that seed-applied neonicotinoids and pyrethroids have similar negative effects on abundance of arthropod natural enemies, PeerJ 4: e2776 (2016).

55 Douglas MR, Rohr JR, and Tooker JF, Neonicotinoid insecticide travels through a soil food chain, disrupting biological control of non-target pests and 
decreasing soya bean yield, J Appl Ecol 52: 250-260 (2015).

56 Takahashi D, Yamanaka T, Sudo M, and Andow DA, Is a larger refuge always better? Dispersal and dose in pesticide resistance evolution, Evolution 71: 1494-1503 (2017).

57 Brier HB, Murray DAH, Wilson LJ, Nicholas AH, Miles MM, Grundy PR, et al., An overview of integrated pest management (IPM) in north-eastern Australian grain farming systems: past, present and future prospects, Aust $J$ Exp Agric 48: 1574-1593 (2008).

58 Peterson RKD, Higley LG, and Pedigo LP, Whatever happened to IPM Am, Entomol 64:146-150 (2018).

59 Scott MJ, Gould F, Lorenzen M, Grubbs N, Edwards O, and O'Brochta D, Agricultural production: assessment of the potential use of Cas9-mediated gene drive systems for agricultural pest control, J Responsible Innov 5:S98-S120 (2018).

60 Downes S, Walsh T, and Tay WT, Bt resistance in Australian insect pest species, Curr Opin Insect Sci 15: 78-83 (2016).

61 Wang J, Wang H, Liu S, Liu L, Tay WT, Walsh TK, et al., CRISPR/Cas9 mediated genome editing of Helicoverpa armigera with mutations of an $\mathrm{ABC}$ transporter gene HaABCA2 confers resistance to Bacillus thuringiensis Cry2A toxins, Insect Biochem Mol Biol 87: 147-153 (2017).

62 Roush RT and Hoy MA, Laboratory, glasshouse, and field studies of artificially selected carbaryl resistance in Metaseiulus occidentalis, J Econ Entomol 74: 142-147 (1981).

63 Harvey-Samuel T, Morrison NI, Walker AS, Marubbi T, Yao J, Collins HL, et $a l$. , Pest control and resistance management through release of insects carrying a male-selecting transgene., BMC Biol 13: 49 (2015).

64 Knox OGG, Constable GA, Pyke B, and Gupta V, Environmental impact of conventional and $B t$ insecticidal cotton expressing one and two Cry genes in Australia., Aust J Agric Res 57: 501-509 (2006).

65 Ferreira SA, Pitz KY, Manshardt R, Zee F, Fitch M, and Gonsalves D, Virus coat protein transgenic papaya provides practical control of Papaya ringspot virus in Hawaii, Plant Dis 86: 101-105 (2002).

66 Barzman M, Bàrberi P, Nicholas A, Birch E, Boonekamp P, DachbrodtSaaydeh S, et al., Eight principles of integrated pest management, Agron 
Sustain Dev 35: 1199-1215 (2015).

67 Jess S, Kildea S, Moody A, Rennick G, Murchie AK, and Cooke LR, European Union policy on pesticides: implications for agriculture in Ireland, Pest Manag Sci 70: 1646-1654 (2014).

68 Carreck NL, A beekeeper's perspective on the neonicotinoid ban, Pest Manag Sci 73: 1295-1298 (2017).

69 Foster J, Government policy strategies relating to the enhanced implementation of integrated pest management: a review, Aust J Environ Manag 2: 234-244 (1995).

70 US EPA, Questions and answers - exclusive use data protection for minor use registrations, EPA office of pesticide programs, US, p. 14 (2014).

71 Powles SB and Gaines TA, Exploring the potential for a regulatory change to encourage diversity in herbicide use, Weed Sci 64: 649-654 (2016).

72 Rane R V, Walsh TK, Pearce SL, Jermiin LS, Gordon KH, Richards S, et al., Are feeding preferences and insecticide resistance associated with the size of detoxifying enzyme families in insect herbivores?, Curr Opin Insect Sci 13: 70-76 (2016).

73 Grains Pest Advisory Committee, A status report on insecticide resistance in Australia, 2016. http://www.cesaraustralia.com/latestnews/sustainableagriculture/benchmarking-insecticide-resistance-in-australia [accessed 15 May 2018].

74 Ridgely AM and Brush SB, Social factors and selective technology adoption: the case of integrated pest management, Hum Organ 51: 367-378 (1992).

75 Gould F, Brown ZS, and Kuzma J, Wicked evolution: Can we address the sociobiological dilemma of pesticide resistance?, Science 360: 728-732 (2018).

76 European Commission, A common methodology for the collection of pesticide usage statistics within agriculture and horticulture, Office for Official Publications of the European Communities, Luxembourg (2008).

77 Baker G, Umina P, Miles M, Schellhorn N, Hoffmann A, Edwards O, et al., The science behind the Resistance Management Strategy for diamondback moth (Plutella xylostella) in Australian canola crops, Grains Research and Development Corporation, Canberra, Australia, p. 22 (2017).

78 Umina P, Hoffmann A, McDonald G, Edwards O, Mangano P, Miles M, et al., The science behind the Resistance Management Strategy for the redlegged 
earth mites (Halotydeus destructor) in Australian grains and pastures, Grains Research and Development Corporation, Canberra, Australia, p. 15 (2016).

79 de Barro PJ, Bemisia tabaci biotype B: a review of its biology, distribution and control. Second edition, CSIRO Aust Div Entomol Tech Pap, CSIRO Division of Entomology, Canberra, Australia (1995).

80 Herron GA, James TM, Rophail J, and Mo J, Australian populations of onion thrips, Thrips tabaci Lindeman (Thysanoptera: Thripidae), are resistant to some insecticides used for their control, Aust J Entomol 47: 361-364 (2008).

81 Herron GA, Langfield BJ, Tomlinson TM, and Mo J, Dose-response testing of Australian populations of onion thrips Thrips tabaci Lindeman (Thysanoptera: Thripidae) further refines baseline data and detects methidathion and likely imidacloprid resistance, Aust J Entomol 50: 418-423 (2011).

82 Manners A, Managing two-spotted mite in production nurseries, Queensland depratment of Agriculture, Fisheries and Forestry, Brisbane, Australia p. 10 (2015).

83 Herron GA, Woolley LK, Langfield KL, and Chen Y, First detection of etoxazole resistance in Australian two-spotted mite Tetranychus urticae Koch (Acarina: Tetranychidae) via bioassay and DNA methods, Austral Entomol 57: 365-368 (2018).

84 Herron GA and Rophail J, First detection of chlorfenapyr (Secure ${ }^{\circledR}$ ) resistance in two-spotted spider mite (Acari: Tetranychidae) from nectarines in an Australian orchard, Exp Appl Acarol 31: 131-134 (2003).

85 Unwin B, Chemical resistance in populations of Tetranychus urticae (Koch) (Acarina: Tetranychidae) from apple orchards in New South Wales, Australia, J Aust Ent Soc 12: 59-67 (1973).

This article is protected by copyright. All rights reserved. 
Table 1. Arthropod species that are economically important pests of Australian grain crops and known to have field resistance

\begin{tabular}{|c|c|c|c|c|c|c|}
\hline Species name & Common name & Australian distribution & $\begin{array}{l}\text { Major agricultural } \\
\text { industries impacted }\end{array}$ & $\begin{array}{l}\text { No. insecticide MoAs } \\
\text { registered in Australia }\end{array}$ & $\begin{array}{l}\text { Documented cases of } \\
\text { resistance in Australia }\end{array}$ & References \\
\hline $\begin{array}{l}\text { Helicoverpa } \\
\text { armigera }\end{array}$ & $\begin{array}{l}\text { Cotton } \\
\text { bollworm }\end{array}$ & $\begin{array}{l}\text { Widespread; most common } \\
\text { in north-eastern Australia }\end{array}$ & $\begin{array}{l}\text { Cotton, grains, } \\
\text { horticulture }\end{array}$ & 8 & $\begin{array}{l}1 \mathrm{~A}, 1 \mathrm{~B}, 3 \mathrm{~A}, 5,11 \mathrm{C}, 22 \mathrm{~A}, \\
28\end{array}$ & 29 \\
\hline $\begin{array}{l}\text { Plutella } \\
\text { xylostella }\end{array}$ & $\begin{array}{l}\text { Diamondback } \\
\text { moth }\end{array}$ & $\begin{array}{l}\text { Widespread; most common } \\
\text { in southern regions }\end{array}$ & $\begin{array}{l}\text { Horticulture, grains, } \\
\text { forage }\end{array}$ & 11 & $1 \mathrm{~A}, 1 \mathrm{~B}, 3 \mathrm{~A}, 5,6,22 \mathrm{~A}, 28$ & 77 \\
\hline $\begin{array}{l}\text { Myzus } \\
\text { persicae }\end{array}$ & $\begin{array}{l}\text { Green peach } \\
\text { aphid }\end{array}$ & Widespread & $\begin{array}{l}\text { Horticulture, grains, } \\
\text { forage }\end{array}$ & 9 & $1 \mathrm{~A}, 1 \mathrm{~B}, 3 \mathrm{~A}, 4 \mathrm{~A}$ & 28,38 \\
\hline $\begin{array}{l}\text { Halotydeus } \\
\text { destructor }\end{array}$ & $\begin{array}{l}\text { Redlegged earth } \\
\text { mite }\end{array}$ & $\begin{array}{l}\text { Restricted to southern } \\
\text { Australia }\end{array}$ & Grains, pastures & 4 & $1 \mathrm{~B}, 3 \mathrm{~A}$ & 78 \\
\hline Bemisia tabaci & $\begin{array}{l}\text { Silverleaf } \\
\text { whitefly }\end{array}$ & $\begin{array}{l}\text { Widespread; most common } \\
\text { in northern regions }\end{array}$ & $\begin{array}{l}\text { Cotton, grains, } \\
\text { horticulture }\end{array}$ & 11 & $1 \mathrm{~A}, 1 \mathrm{~B}, 3 \mathrm{~A}, 4 \mathrm{~A}, 7 \mathrm{C}, 16$ & \begin{tabular}{|l|l|}
73,79 \\
\end{tabular} \\
\hline $\begin{array}{l}\text { Frankliniella } \\
\text { occidentalis }\end{array}$ & $\begin{array}{l}\text { Western flower } \\
\text { thrip }\end{array}$ & Widespread & Cotton, horticulture & 6 & $1 \mathrm{~A}, 1 \mathrm{~B}, 3 \mathrm{~A}, 4 \mathrm{~A}, 5$ & 3,73 \\
\hline Thrips tabaci & Onion thrip & Widespread & Horticulture, grains & 6 & $1 \mathrm{~B}, 3 \mathrm{~A}, 4 \mathrm{~A}$ & 80,81 \\
\hline $\begin{array}{l}\text { Tetranychus } \\
\text { urticae }\end{array}$ & $\begin{array}{l}\text { Two spotted } \\
\text { mite }\end{array}$ & Widespread & $\begin{array}{l}\text { Cotton, grains, } \\
\text { horticulture }\end{array}$ & 13 & $\begin{array}{l}1 \mathrm{~B}, 3 \mathrm{~A}, 10 \mathrm{~A}, 10 \mathrm{~B}, 12 \mathrm{~B} \\
12 \mathrm{C}, 12 \mathrm{D}, 13,21 \mathrm{~A}, \mathrm{UN}^{\ddagger}\end{array}$ & $82-85$ \\
\hline
\end{tabular}

${ }^{\dagger}$ IRAC chemical Mode of Action sub-groups. Does not include registered chemicals which are not listed in the IRAC classification (e.g. paraffinic oils). Source: APVMA, 2018.

${ }^{\ddagger}$ Dicofol has unknown Mode of Action classification (UN).

This article is protected by copyright. All rights reserved. 
Table 2. Suggested practices within the Australian grains industry and interventions to more strategically manage insecticide resistance

\begin{tabular}{|c|c|c|c|c|c|c|c|c|}
\hline & \multicolumn{2}{|c|}{ Industry practices } & \multicolumn{6}{|c|}{ On-farm pest management practices } \\
\hline & $\begin{array}{l}\text { Industry } \\
\text { awareness and } \\
\text { engagement in } \\
\text { resistance }\end{array}$ & $\begin{array}{l}\text { Knowledge of } \\
\text { resistance risks }\end{array}$ & $\begin{array}{l}\text { Proactive pest } \\
\text { management }\end{array}$ & $\begin{array}{l}\text { Pest } \\
\text { monitoring }\end{array}$ & $\begin{array}{l}\text { Economic } \\
\text { thresholds for } \\
\text { pests }\end{array}$ & $\begin{array}{l}\text { Beneficial } \\
\text { organisms }\end{array}$ & Insecticide choice & $\begin{array}{l}\text { MoAs available } \\
\text { and applied } \\
\text { strategically }\end{array}$ \\
\hline $\begin{array}{l}\text { Common } \\
\text { practice }\end{array}$ & $\begin{array}{l}\text { Little cross- } \\
\text { industry } \\
\text { collaboration. } \\
\text { Baseline } \\
\text { sensitivity data } \\
\text { generally not } \\
\text { available }\end{array}$ & $\begin{array}{l}\text { Poor knowledge } \\
\text { of risks for } \\
\text { many pests, } \\
\text { chemicals }\end{array}$ & $\begin{array}{l}\text { Occasional. } \\
\text { Regional } \\
\text { differences exist }\end{array}$ & $\begin{array}{l}\text { Occasional. } \\
\text { Often } \\
\text { perceived as } \\
\text { too labour } \\
\text { intensive }\end{array}$ & $\begin{array}{l}\text { Occasional. } \\
\text { Only a few } \\
\text { reliable } \\
\text { thresholds } \\
\text { available }\end{array}$ & $\begin{array}{l}\text { Underutilised } \\
\& \text { lack of } \\
\text { confidence in } \\
\text { their capacity }\end{array}$ & $\begin{array}{l}\text { Broad-spectrum } \\
\text { insecticides } \\
\text { widely used as } \\
\text { first management } \\
\text { tactic }\end{array}$ & $\begin{array}{l}\text { Occasionally } \\
\text { applied. Few } \\
\text { MoA options to } \\
\text { rotate }\end{array}$ \\
\hline $\begin{array}{l}\text { Optimal } \\
\text { practice }\end{array}$ & $\begin{array}{l}\text { Integrated } \\
\text { resistance } \\
\text { management } \\
\text { applied across } \\
\text { commodities. } \\
\text { Affordable tools } \\
\text { to rapidly test for } \\
\text { resistance }\end{array}$ & $\begin{array}{l}\text { Industry \& } \\
\text { farmers } \\
\text { understand risks } \\
\text { and implement } \\
\text { appropriate } \\
\text { resistance } \\
\text { management }\end{array}$ & $\begin{array}{l}\text { Pest populations } \\
\text { reduced ahead } \\
\text { of cropping } \\
\text { season using } \\
\text { diverse IPM } \\
\text { tactics }\end{array}$ & $\begin{array}{l}\text { Farmers } \\
\text { respond to } \\
\text { spatial \& } \\
\text { temporal pest } \\
\text { threats in a } \\
\text { timely } \\
\text { manner }\end{array}$ & $\begin{array}{l}\text { Economic } \\
\text { thresholds } \\
\text { used widely to } \\
\text { inform } \\
\text { management } \\
\text { decisions }\end{array}$ & $\begin{array}{l}\text { Beneficials } \\
\text { better } \\
\text { understood, } \\
\text { monitored \& } \\
\text { utilised }\end{array}$ & $\begin{array}{l}\text { Cost-effective } \\
\text { selective } \\
\text { insecticides used } \\
\text { routinely }\end{array}$ & $\begin{array}{l}\text { A range of } \\
\text { MoAs available } \\
\& \text { rotated } \\
\text { strategically }^{\dagger}\end{array}$ \\
\hline $\begin{array}{l}\text { Interventions } \\
\text { required }\end{array}$ & $\begin{array}{l}\text { Cross-industry } \\
\text { investment } \\
\text { through national } \\
\text { initiatives }\end{array}$ & $\begin{array}{l}\text { Resistance } \\
\text { monitoring \& } \\
\text { testing services. } \\
\text { Ecological \& } \\
\text { chemical data }\end{array}$ & $\begin{array}{l}\text { Greater } \\
\text { incorporation of } \\
\text { emerging } \\
\text { technologies. } \\
\text { Communication }\end{array}$ & $\begin{array}{l}\text { Emerging } \\
\text { technologies } \\
\text { to automate/ } \\
\text { simplify } \\
\text { monitoring }\end{array}$ & $\begin{array}{l}\text { RD\&E in } \\
\text { economic } \\
\text { thresholds for } \\
\text { key pests }\end{array}$ & $\begin{array}{l}\text { RD\&E to } \\
\text { improve IPM } \\
\text { options. } \\
\text { Policy } \\
\text { changes that }\end{array}$ & $\begin{array}{l}\text { Regulatory } \\
\text { withdrawal of } \\
\text { older, broad- } \\
\text { spectrums \& } \\
\text { policy support for }\end{array}$ & $\begin{array}{l}\text { Communication } \\
\& \text { engagement. } \\
\text { Increased } \\
\text { regulation to } \\
\text { support new }\end{array}$ \\
\hline
\end{tabular}

This article is protected by copyright. All rights reserved. 
${ }^{\dagger}$ The mechanism of resistance is important for rotational strategies and resistance to different mechanisms needs to be genetically independent. For instance, if the same resistance mechanism of enhanced P450 metabolism acts across different MoAs, rotation of MoAs may not be effective. 


\section{University Library}

\section{- M I I N E R VA \\ A gateway to Melbourne's research publications}

Minerva Access is the Institutional Repository of The University of Melbourne

Author/s:

Umina, PA;McDonald, G;Maino, J;Edwards, O;Hoffmann, AA

Title:

Escalating insecticide resistance in Australian grain pests: contributing factors, industry trends and management opportunities

Date:

2019-06-01

\section{Citation:}

Umina, P. A., McDonald, G., Maino, J., Edwards, O. \& Hoffmann, A. A. (2019). Escalating insecticide resistance in Australian grain pests: contributing factors, industry trends and management opportunities. PEST MANAGEMENT SCIENCE, 75 (6), pp.1494-1506. https:// doi.org/10.1002/ps.5285.

Persistent Link:

http://hdl.handle.net/11343/285360 